\title{
Effect of Fish Bone Bioactive Peptides on Oxidative, Inflammatory and Pigmentation Processes Triggered by UVB Irradiation in Skin Cells
}

\author{
Andreea Iosageanu ${ }^{1,+} \mathbb{D}$, Daniela Ilie ${ }^{1,+}$, Oana Craciunescu ${ }^{1, * \mathbb{D}}$, Ana-Maria Seciu-Grama ${ }^{1}$, Anca Oancea ${ }^{1}$, \\ Otilia Zarnescu ${ }^{2}$, Ionut Moraru ${ }^{3}$ (D) and Florin Oancea ${ }^{4}(\mathbb{D}$
}

1 National Institute of R\&D for Biological Sciences, 296, Splaiul Independentei, 060031 Bucharest, Romania; andreea.iosageanu@gmail.com (A.I.); danielailiee24@gmail.com (D.I.); ana.seciu@yahoo.com (A.-M.S.-G.); oancea.anca@gmail.com (A.O.)

2 Faculty of Biology, University of Bucharest, 91-95, Splaiul Independentei, 050095 Bucharest, Romania; otilia.zarnescu@bio.unibuc.ro

3 Laboratoarele Medica SRL, 11, Frasinului Street, 075100 Otopeni, Romania; ionutmoraru@pro-natura.ro

4 National Institute for R\&D in Chemistry and Petrochemistry-Icechim, 202, Splaiul Independentei, 060021 Bucharest, Romania; florin.oancea@icechim.ro

* Correspondence: oana_craciunescu2009@yahoo.com

+ These authors have equally contributed to this work.

Citation: Iosageanu, A.; Ilie, D.; Craciunescu, O.; Seciu-Grama, A.-M.; Oancea, A.; Zarnescu, O.; Moraru, I.; Oancea, F. Effect of Fish Bone Bioactive Peptides on Oxidative, Inflammatory and Pigmentation Processes Triggered by UVB Irradiation in Skin Cells. Molecules 2021, 26, 2691. https://doi.org/ $10.3390 /$ molecules26092691

Academic Editor: Dana Maria Copolovici

Received: 15 April 2021

Accepted: 3 May 2021

Published: 4 May 2021

Publisher's Note: MDPI stays neutral with regard to jurisdictional claims in published maps and institutional affiliations.

Copyright: (c) 2021 by the authors. Licensee MDPI, Basel, Switzerland. This article is an open access article distributed under the terms and conditions of the Creative Commons Attribution (CC BY) license (https:/ / creativecommons.org/licenses/by/ $4.0 /)$.

\begin{abstract}
In the present study, we evaluated for the first time the photoprotective effect of fish bone bioactive peptides (FBBP) preparation isolated from silver carp (Hypophthalmichthys molitrix) discarded tissue using in vitro experimental models of skin cells exposed to ultraviolet B (UVB) irradiation and stressing agents. FBBP preparation was obtained by papain treatment of minced bones and centrifugal ultrafiltration, and the molecular weight (MW) distribution was characterized by size exclusion and reversed-phase high performance liquid chromatography (RP-HPLC). In vitro assessment of the effect of FBBP pretreatment in UVB-irradiated L929 fibroblasts and HaCaT keratinocytes revealed their cytoprotective activity. Their capacity to efficiently reduce reactive oxygen species (ROS) production and lipid peroxidation varied in a dose-dependent manner, and it was greater in fibroblasts. A decrease of proinflammatory cytokines secretion, in particular of tumor necrosis factor alpha (TNF- $\alpha$ ), was found after FBBP pretreatment of THP-1-derived inflamed macrophages. Melanin production and tyrosinase activity investigated in UVB-irradiated Mel-Juso cells were lowered in direct relation to FBBP concentrations. FBBP fractions with high radical scavenging activity were separated by ion exchange chromatography, and two collagenic sequences were identified. All these results offer new scientific data on aquaculture fish bone-derived peptides confirming their ability to control the antioxidant, anti-inflammatory and pigmentation processes developed during UV irradiation of skin cells and recommend their use as valuable natural ingredients of photoprotective cosmeceutical products.
\end{abstract}

Keywords: collagen peptides; free radicals scavenging; antioxidant activity; biological activity; proinflammatory cytokines; melanogenesis; lipid peroxidation; photoaging; sunscreen

\section{Introduction}

$\mathrm{UV}$ radiation is considered one of the most dangerous environmental factor that produces minor skin conditions, such as erythema, roughness, pigmentation and wrinkles, but also melanoma and non-melanoma skin cancer [1]. In 2012, The International Agency for Research on Cancer classified UV radiation as carcinogenic to humans. Studies have shown that prolonged exposure to UV radiation triggered the activation of cytokines and growth factor receptors, leading to an inflammatory response and overexpression of metalloproteinases (MMPs), such as collagenases (MMP-1 and MMP-8), stromelysin (MMP3) and gelatinases (MMP-2 and MMP-9), involved in the degradation of the extracellular 
matrix and, consequently, causing connective tissue remodeling [2]. Among the three types of UV radiation, UVB is known to be responsible for cancer and other skin conditions due to penetration of epidermis and upper dermis [3]. The excessive production of ROS after UVB exposure caused changes in skin cells structure and function, cell cycle progression and accumulation of mutations [4].

Skin photoprotection can be topically or orally provided by administration of natural compounds, such as vitamins, polyphenols and flavonoids, which mainly act as free radical scavengers and antioxidants [5]. In the past few years, the protective effect of fish bioactive peptides has been extensively studied, and has been shown to inhibit MMP-1 and MMP2 and stimulate the biosynthesis of fibrillar collagen types I and III in the extracellular matrix [6]. It was documented that the aquatic species represent a remarkable source of biologically active compounds with antioxidant, anti-inflammatory and antimicrobial properties, which make them suitable for medical and cosmeceutical use [7]. In addition, replacement of land vertebrates with marine and freshwater fish can prevent the spread of contagious diseases, such as bovine spongiform encephalopathy and swine fever, as well as respond to religious restrictions of animal protein consumption [6].

Although several marine sources were exploited hitherto [8], in the present study, the possibility of harnessing new bioactive compounds from aquaculture fishery by-products was explored, in order to reuse them in the cosmeceutical industry. Every year, millions of tons of fish are destined for human consumption, but only a small part of the waste is reused. In many countries, fish skin, head, fins, skeleton and viscera are thrown away, causing environmental problems, or, at best, they are reused as animal feed. For this reason, fish waste valorization by tissue enzymatic hydrolysis has been proposed for the extraction of bioactive peptides [9]. This method has numerous advantages, such as mild reaction conditions, enzyme specificity and control of the hydrolysis degree [10]. Many commercial proteases, such as alcalase, papain, pepsin, trypsin, $\alpha$-chymotrypsin, pancreatin, flavourzyme, pronase, neutrase, protamex, bromelain, cryotin $\mathrm{F}$, protease $\mathrm{N}$, protease A, orientase, thermolysin and validase, have been tested in different conditions, varying the reaction parameters, such as temperature, time and $\mathrm{pH}[6,11,12]$. The silver carp (H. molitrix) is an aquaculture species belonging to the Cyprinidae freshwater family of fishes. Studies on the enzymatic hydrolysis of its waste tissues discarded after industrial processing have mainly focused on skin [13] and muscle [14-16]. Papain treatment of discarded $H$. molitrix bones followed by centrifugal ultrafiltration resulted in a peptides mixture containing low MW compounds useful as dietary supplement after microencapsulation with flavonoids [17]. Preliminary data on the preparation's ability to stimulate cell adhesion and migration in human keratinocytes culture were also reported, as the main processes during skin wound healing [18], which required further investigations.

It was previously shown that protein hydrolysates obtained from the skin of marine fish, such as cobia (Rachycentron canadum) [19], cod (Gadus macrocephalus) [20], croaker (Otolithes ruber), horse mackerel (Magalaspis cordyla) [21], pollock (Pollachius virens) [22] and righteye flounders [23] provided an important source of antioxidant and immunomodulatory peptides. Moreover, a study reported that tilapia fish skin gelatin hydrolysates contained a hexapeptide, which decreased ROS generation in UV-irradiated mouse embryonic fibroblasts [24].

In addition, bioactive peptides containing collagen-like sequences could exert photoprotective effect on irradiated skin and efficiency in photoaging by their ability to delay the onset of wrinkles, inhibit the involved MMPs [25] and reduce melanin synthesis as a result of tyrosinase inhibition [26]. Oral administration of Pacific cod (Gadus macrocephalus) hydrolysates influenced MMPs inhibition in UV-exposed mice skin [27], while that of collagen peptides from silver carp skin induced antioxidant activity in UV-irradiated mice skin [28]. In most studies, peptides with a MW ranging 100-3000 Da exerted stronger antioxidant effect, mostly due to easier penetration of the gastrointestinal and skin barrier and facilitation of cellular uptake. 
The aim of the present study was to characterize the FBBP preparation isolated from H. molitrix to investigate the photoprotective effect using in vitro experimental models of skin cells exposed to UVB-irradiation, oxidative stress and inflammation and identify the sequence of peptides exerting high antiradical activity. FBBP cytoprotection and ROS production were evaluated in stressed L929 fibroblasts and HaCaT keratinocytes cultures; anti-inflammatory activity was analyzed in THP-1-derived inflamed macrophages; and melanogenesis was assessed in irradiated Mel-Juso cell culture, in order to investigate peptides use as valuable natural ingredients for the development of new cosmeceuticals with photoprotective and anti-photoaging effect. No studies on fish bone peptides action in $\mathrm{HaCaT}$ and THP-1 cell cultures were found in the scientific literature.

\section{Results and Discussion}

\subsection{Fish Bone Peptides Preparation}

Bone matrix is primarily consisting of type I collagen (90\% of total protein) [29]. Pretreatment stage and papain enzymatic treatment in controlled conditions of discarded H. molitrix bones provided a fish bone protein hydrolysate (FBH). The following centrifugal ultrafiltration produced an opalescent solution of FBBP having $92.6 \%$ peptides content, which indicated an easy and efficient technology, recommended for scale-up. The yield of $\mathrm{FBH}$ preparation was $54.16 \%(w / w)$, while that of FBBP preparation was $7.08 \%(w / w)$ in a dry weight (d.w.) basis. It was documented that fish hydrolysate has generally provided low debris quantity, compared to land vertebrate collagen hydrolysates subjected to filtration, facilitating a low-cost process [29].

Several fish bone tissues have been previously processed by enzymatic hydrolysis using various enzymes to produce antioxidant peptides with different MW and sequence (Table 1). No study was found on antioxidant peptides prepared by papain-treatment of silver carp bones.

Table 1. Antioxidant activity of fish bone peptides.

\begin{tabular}{|c|c|c|c|}
\hline Source & Enzyme & Sequence (MW) & Antioxidant Activity \\
\hline $\begin{array}{c}\text { Hoki (Johnius belengerii) frame } \\
\text { protein }\end{array}$ & $\begin{array}{l}\text { Pepsin, trypsin, papain, } \\
\text { a-chymotrypsin, alcalase, } \\
\text { neutrase }\end{array}$ & $\begin{array}{l}\text {-ESTVPERTHPACPDF- } \\
\text { (1801 Da) }\end{array}$ & $\begin{array}{l}\text { 2,2-diphenyl-1-picrylhydrazyl } \\
\text { (DPPH), HO, superoxide, peroxyl } \\
\text { radical scavenging activity } \\
\text { Lipid peroxidation inhibition [30] }\end{array}$ \\
\hline $\begin{array}{c}\text { Tuna (Thunnus orientalis) } \\
\text { backbone }\end{array}$ & $\begin{array}{l}\text { Alcalase, } \alpha \text {-chymotrypsin, } \\
\text { neutrase, papain, pepsin, } \\
\text { trypsin }\end{array}$ & $\begin{array}{l}\text {-VKAGFAWTANQQLS- } \\
\text { (1519 Da) }\end{array}$ & $\begin{array}{l}\text { DPPH, HO, superoxide radical } \\
\text { scavenging activity, } \\
\text { Lipid peroxidation inhibition [31] }\end{array}$ \\
\hline $\begin{array}{c}\text { Atlantic cod (Gadus morhua) } \\
\text { backbone }\end{array}$ & Bacterial protease (Protamex) & -WMDF- & $\begin{array}{c}\text { DPPH radical scavenging activity } \\
\text { [32] }\end{array}$ \\
\hline Salmon (Salmo salar) backbone & $\begin{array}{l}\text { Bacterial endopeptidase } \\
\left.\text { (Corolase }{ }^{\circledR 囚} 7089\right), \\
\text { bacterial protease } \\
\left.\text { (Protamex }^{\circledR \cap}\right), \text { papain, } \\
\text { bromelain, trypsin }\end{array}$ & - & $\begin{array}{l}\text { DPPH radical scavenging activity } \\
\text { [33] }\end{array}$ \\
\hline $\begin{array}{c}\text { Skipjack tuna } \\
\text { (Katsuwonus pelamis) bone }\end{array}$ & Trypsin, chymotrypsin & $\begin{array}{c}\text {-SSGPPVPGPMGPMGPR- } \\
\text { (1520 Da) }\end{array}$ & $\begin{array}{c}\text { DPPH, ABTS, superoxide radical } \\
\text { scavenging activity [34] }\end{array}$ \\
\hline $\begin{array}{c}\text { Snapper fish } \\
\text { (Lutjanus campechanus) scales }\end{array}$ & Alcalase & $<5000 \mathrm{Da}$ & $\begin{array}{c}\text { ABTS, HO radical scavenging } \\
\text { activity [35] }\end{array}$ \\
\hline
\end{tabular}

\subsection{MW Distribution}

MW distribution of peptides from FBBP preparation was analyzed by size exclusion and RP-HPLC. The chromatograms are presented in Figure 1.

The results of size exclusion chromatography showed that the ultrafiltered FBBP preparation presented a single elution peak, while FBH had a minor peak at high MW and a wide shoulder peak. However, the asymmetric shape of the FBBP peak indicated non-homogeneous distribution of peptides MW. A higher elution volume $(67 \%, v / v)$ corresponded to FBBP having lower MW ranging 700-7000 Da, according to the calculations 
based on the standard curve (Figure 1a). These results indicate that papain treatment of silver carp bones for $6 \mathrm{~h}$ yielded FBH consisting of a heterogeneous mixture of oligopeptides, while the additional centrifugal filtration step led to separation of FBBP, a homogeneous fraction rich in low MW peptides.
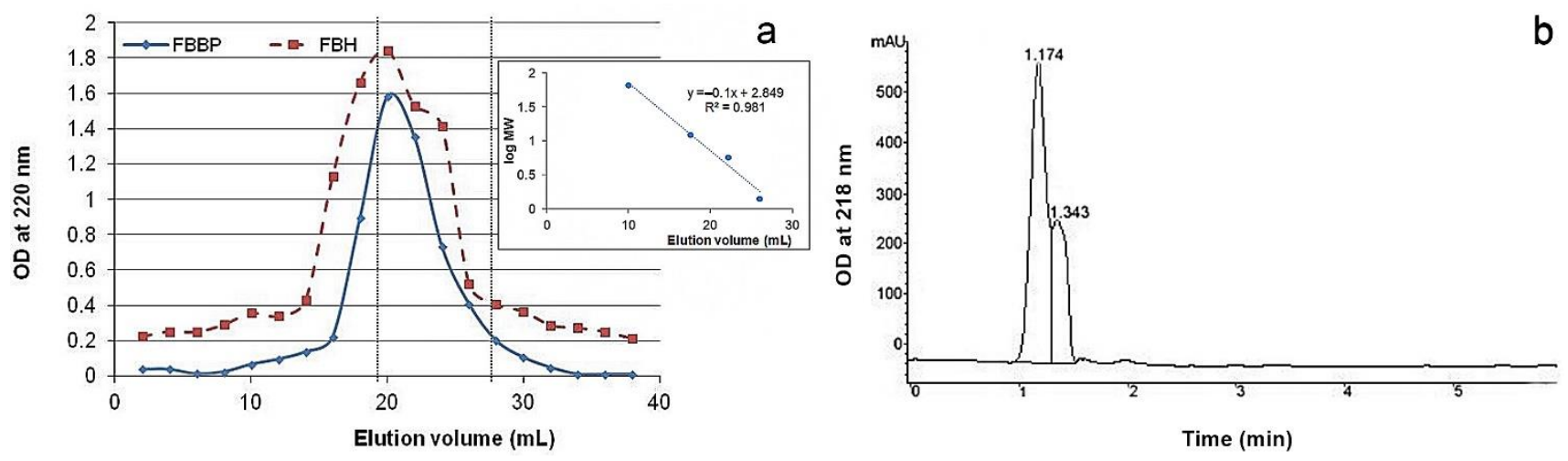

Figure 1. MW distribution of peptides isolated from H. molitrix bones determined by chromatography analyses: (a) Size exclusion chromatography of FBH and FBBP filtered preparation on Sephadex G-75. The insert represents the standard curve built using proteins of known MW (albumin, cytochrome c, insulin and bacitracin). (b) RP-HPLC of FBBP on Europa C18 peptide column.

The profile registered by RP-HPLC analysis presented a split peak at 1.174 and $1.343 \mathrm{~min}$ (Figure $1 \mathrm{~b}$ ). The peaks corresponding to retention times under $5 \mathrm{~min}$ were likely to contain small, hydrophilic fragments or free amino acids, as reported for other enzymatic fish hydrolysates [36].

\subsection{UV Spectroscopy}

Serially diluted concentrations of FBBP preparation were analyzed for the ability to absorb UV radiation by spectra registration on each UV domain, namely UVC (220-290 nm), UVB (290-320 nm) and UVA (320-400 nm). The results are presented in Figure S1. From the values of UV absorption factor, it was observed that FBBP could efficiently absorb UVC radiation (65-91\%) and partially absorbed UVB (25-41\%) and UVA (20-24\%) radiation (Figure 2). The absorption capacity varied in a dose-dependent manner, especially in the case of UVC and UVB radiation. A commercial SPF 6 lotion used as control showed high values of UV absorption factor in all domains, varying from $81 \%$ in UVC to $64 \%$ in UVA (Figure 2).

A sunscreen provides protection on the entire UV domain $(200-400 \mathrm{~nm})$ due to constituent organic and inorganic filters that absorb and reflect, respectively, the UV radiation $[37,38]$. Plant extracts and, in particular, polyphenolic compounds, such as rutin, ferulic acid and caffeine were clinically tested as natural UV filters and provided enhanced photoprotection to traditional sunscreens, delaying erythema through different mechanisms of antioxidant and anti-inflammatory action [38]. Gelatin peptides conditioned as nanoparticles played an even more important role than rutin, enhancing the antioxidant/anti-inflammatory results, but showed no efficacy against UVB radiation [38]. In our study, FBBP preparation presented variable UV absorption, according to its concentration and UV domain. The high UVC absorption is not relevant for a sunscreen, as these rays are blocked by the ozone layer. Due to low FBBP capacity to absorb UVB and UVA radiation involved in producing erythema, solar burns or even melanoma, they could not be considered chemical filters for sunscreens. Despite of this observation, we continued the research, at the cellular level, using experimental models that mimicked the processes taking place in the irradiated skin, in order to investigate their biological efficiency and effect on the metabolism of skin cells. 


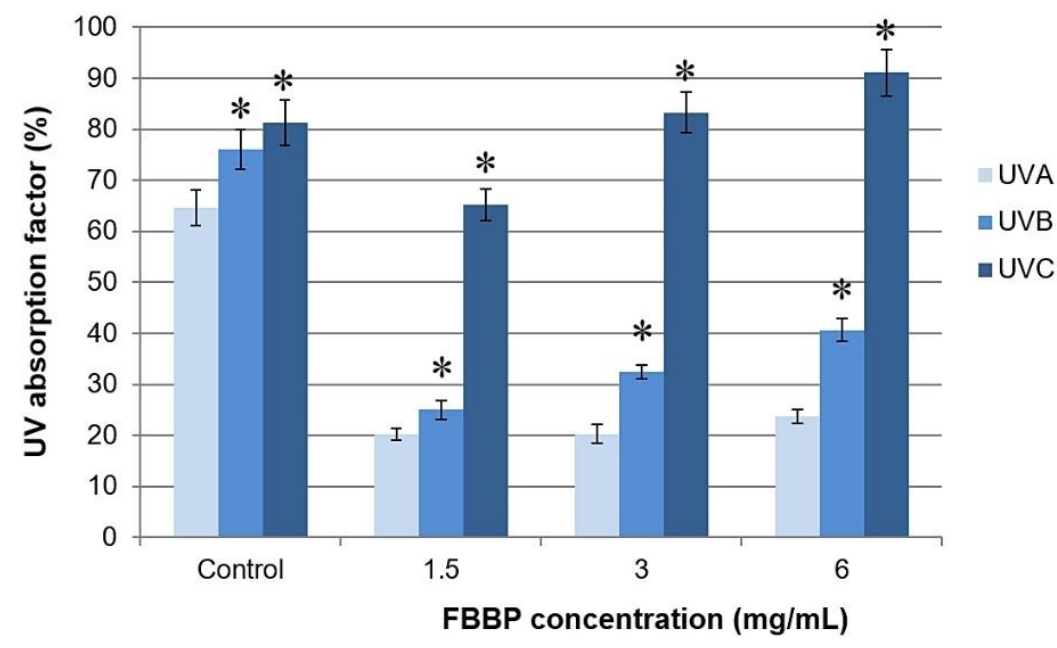

Figure 2. UV absorption factor of fish bone bioactive peptides (FBBP) preparation isolated from H. molitrix and commercial SPF6 lotion (control) in UVA, UVB and UVC domain, at different concentrations. The values were reported as percentage and expressed as mean $\pm \operatorname{SD}(n=3) .{ }^{*} p<0.05$, compared to UVA.

\subsection{Cytocompatibility of FBBP in L929 and HaCaT Cells}

In vitro cytocompatibility of FBBP isolated from discarded $H$. molitrix bones was evaluated towards skin cells, in an experimental model of direct contact, according to ISO 10993-5 for cytotoxicity testing of medical devices by 3-(4,5-dimethylthiazol-2-yl)-2,5diphenyl-tetrazolium bromide (MTT) assay and light microscopy observations. The results obtained in L929 fibroblast and HaCaT keratinocyte cultures are presented in Figure 3.

In L929 cells, FBBP presented a wide range of cytocompatibility with cell viability values above $80 \%$ in the range of concentrations of $10-500 \mu \mathrm{g} / \mathrm{mL}$ (Figure 3a). At higher concentrations, the cell viability decreased in a dose-dependent manner, reaching $60 \%$ cell viability at a concentration of $1500 \mu \mathrm{g} / \mathrm{mL}$ FBBP. It was observed that the treatment with $10-120 \mu \mathrm{g} / \mathrm{mL}$ FBBP significantly $(p<0.05)$ increased the cell proliferation of L929 cells, compared to the untreated control. The highest increase of cell proliferation (1.1-fold) was recorded at a concentration of $30 \mu \mathrm{g} / \mathrm{mL}$ FBBP and ascorbic acid (AA) (1.05-fold), a known bioactive agent with key role in skin health.

In $\mathrm{HaCaT}$ cells, FBBP were cytocompatible at a wide range of concentrations $(10-1000 \mu \mathrm{g} / \mathrm{mL})(>80 \%$ cell viability) and presented only a slight decrease to $74 \%$ cell viability at a concentration of $1500 \mu \mathrm{g} / \mathrm{mL}$ (Figure 3a). The keratinocytes proliferation was significantly $(p<0.05)$ stimulated by 1.12 -fold, at a concentration of $120 \mu \mathrm{g} / \mathrm{mL}$ FBBP, similar to AA treatment (1.07-fold).

Light micrographs showed that cells treated with different concentrations of FBBP presented a similar morphology to that of the untreated cells, in both L929 fibroblast and $\mathrm{HaCaT}$ keratinocyte cultures, confirming peptides cytocompatibility with skin cells (Figure $3 b$ ). The cultures displayed the characteristic phenotype of adhered cells, spread on the entire surface, and the cell density was similar to that of control and AA-treated cells.

\subsection{Cytoprotective Effect of FBBP in UVB-Irradiated L929 and HaCaT Cells}

The cytoprotective capacity of FBBP investigated in the UVB-irradiated experimental model of cultured skin cells was investigated in the same range of concentrations. MTT results show that FBBP treatment applied to L929 fibroblasts prior to UVB irradiation was able to significantly $(p<0.05)$ stimulate the cell metabolism, at concentrations of $30-120 \mu \mathrm{g} / \mathrm{mL}$ (Figure $4 \mathrm{a}$ ). The values of cell viability were 1.03-1.09-fold higher than that of UV-treated control cells and similar to that of AA-treated cells (1.05-fold), at $24 \mathrm{~h}$ postexposure. The maximum value of cell viability $(109.21 \%)$ was recorded at a concentration of $60 \mu \mathrm{g} / \mathrm{mL}$ FBBP. Similarly, pretreatment of $\mathrm{HaCaT}$ cells with different concentrations of 
FBBP $(30-500 \mu \mathrm{g} / \mathrm{mL})$ significantly $(p<0.05)$ increased the cell viability by $1.05-1.16$-fold, with a maximum value recorded at $120 \mu \mathrm{g} / \mathrm{mL}$ FBBP (115.88\%) (Figure 4a).

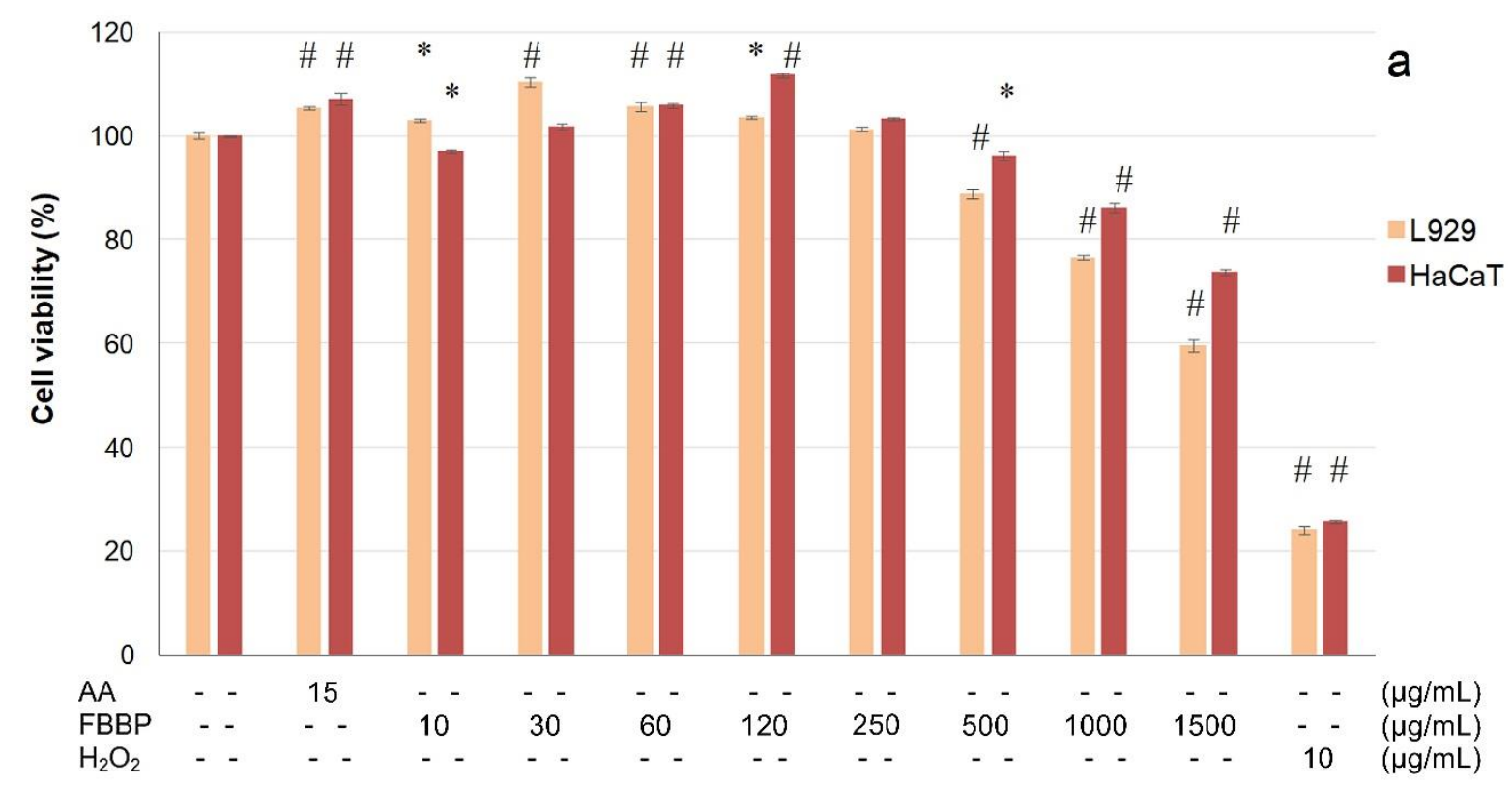

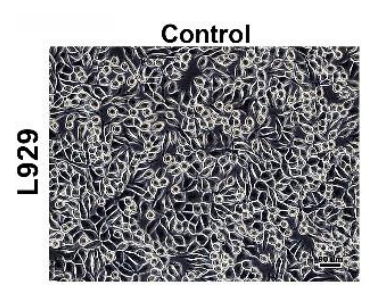

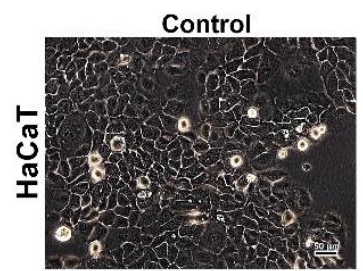

AA
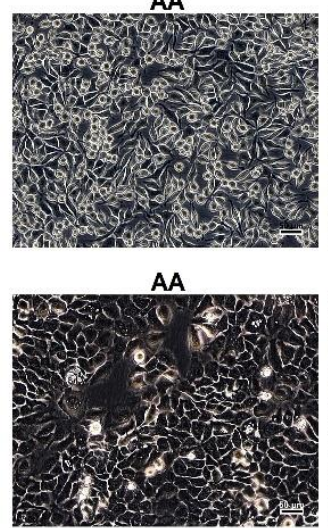

FBBP 10

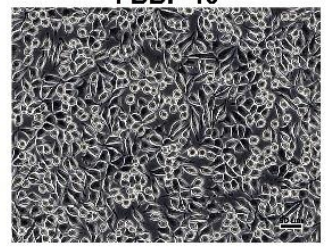

FBBP 60

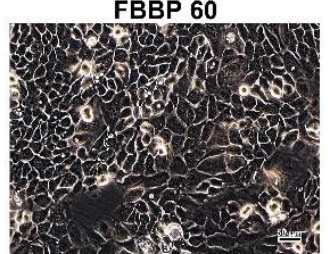

FBBP 30

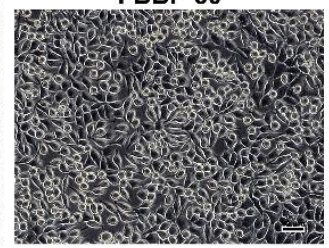

FBBP 120

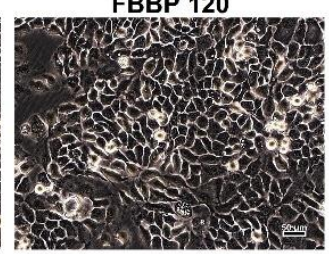

FBBP $60 \quad b$

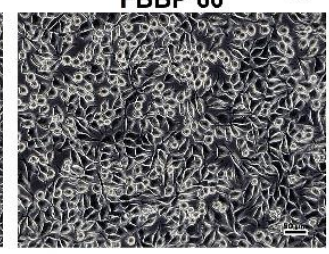

FBBP 250

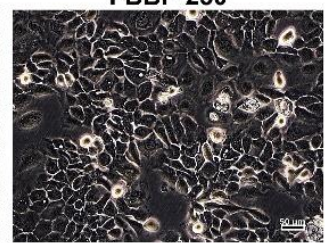

Figure 3. Cell viability of L929 and HaCaT cells cultivated in the presence of different concentrations of FBBP and AA at $48 \mathrm{~h}$ of cultivation, evaluated by MTT assay (a). The values are expressed as mean $\pm \operatorname{SD}(n=3) .{ }^{*} p<0.05,{ }^{\#} p<0.01$, compared to the untreated cells (control). Cells treated with $\mathrm{H}_{2} \mathrm{O}_{2}$ served as positive control. Phase contrast microscopy observations of cell morphology in L929 and HaCaT cells cultivated in the presence of different concentrations of FBBP (b). Scale bar $=50 \mu \mathrm{m}$.

Cell morphology observations performed immediately post-UVB exposure showed that irradiated cells (UVB control) presented altered characteristics with numerous globular cells in suspension (data not shown). In turn, FBBP-pretreated cells had few globular cells in suspension and the majority of cells adhered to the surface, indicating peptides capacity to protect skin cells against UVB action (data not shown). At $24 \mathrm{~h}$ post-UVB exposure, the morphological analysis of FBBP-pretreated cells confirmed the photoprotection of L929 cells at $10-60 \mu \mathrm{g} / \mathrm{mL}$ concentrations and that of $\mathrm{HaCaT}$ cells at $60-250 \mu \mathrm{g} / \mathrm{mL}$ concentrations (Figure 4b).

Similar studies showed that an antioxidant peptide of 1673 Da isolated from frog skin secretions had the ability to penetrate the cell membrane of HaCaT keratinocytes and to stimulate in vitro migration mechanisms, but also to prevent skin inflammation and photoaging of UVB irradiated mice skin by topical administration [39]. Collagen peptides from deer tendon with MW 5-13 kDa were able to penetrate the mice skin, unlike native collagen, and promoted cell proliferation [40]. In vivo studies reported that tilapia scales 
collagen peptides of 3.5-4.5 kDa showed better penetration of mice stratum corneum than smaller peptides $(1.3 \mathrm{kDa})$ and improved women skin moisture and elasticity [41]. Studies on UV-irradiated mice fed with antioxidant peptides of 1-3 kDa from silver carp skin gelatin exerted the best protecting effect on skin structure, compared to casein peptides [28]. Moreover, consumption and absorption of fish scale collagen dipeptides, such as Gly-Pro and Pro-Hyp, enhanced skin properties, reducing UVB-induced aging [42].
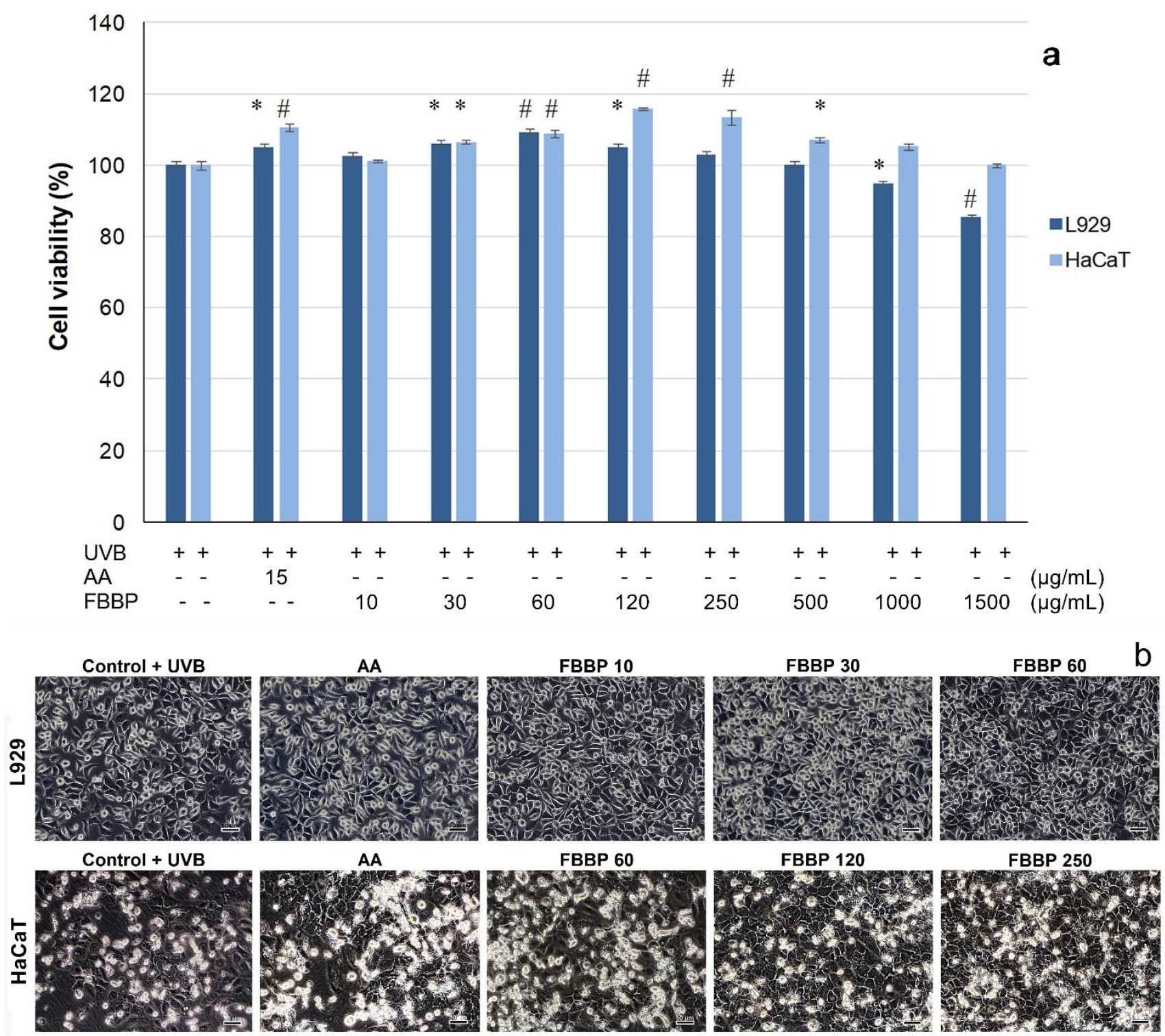

Figure 4. Cell viability of L929 and HaCaT pretreated with different concentrations of FBBP and AA, exposed to UVB irradiation and cultivated for $24 \mathrm{~h}$, as determined by MTT assay (a). The values are expressed as mean $\pm \operatorname{SD}(n=3)$. ${ }^{*} p<0.05$ and ${ }^{\#} p<0.01$, compared to UV control. $\mathrm{H}_{2} \mathrm{O}_{2}$-treated cells served as positive control. Light microscopy observations of cell morphology in UVB-irradiated L929 and HaCaT cells pretreated with different concentrations of $\operatorname{FBBP}(\mathbf{b})$. Bar scale $=50 \mu \mathrm{m}$.

The results of the present study show that FBBP isolated from industrial waste bones of silver carp could stimulate the metabolism and cell proliferation of fibroblasts and keratinocytes. In addition, FBBP preparation demonstrated cytoprotective activity in an experimental model of UVB-irradiated skin cells, which suggested usefulness in topical formulations intended for skin protection against photoaging. Further, we investigated the effect of optimal concentrations of FBBP $(60$ and $120 \mu \mathrm{g} / \mathrm{mL}$ ) on processes triggered by UVB irradiation, such as intracellular ROS production, level of inflammation and melanogenesis in several in vitro experimental models mimicking those taking place in skin. 


\subsection{Effect of FBBP on Intracellular ROS Production in Skin Cells}

UVB irradiation of skin cells leads to excessive ROS production and, consequently, to damage of biomolecules present in the cell membrane, disturbances in cell metabolism and enzyme secretion [2]. In the present study, FBBP effect on intracellular ROS and malondialdehyde (MDA) production was investigated, for the first time, in both experimental models of oxidative stressed fibroblasts and keratinocytes, in regard of their role as protective agents against oxidative damage and lipid peroxidation. Flow cytometry histograms and the values of intracellular ROS production calculated using Diva software are presented in Figure 5.

The results show that the level of ROS production significantly $(p<0.05)$ decreased down to $8.22 \%$ in $\mathrm{L} 929$ cells (Figure $5 \mathrm{a}$ ), while in $\mathrm{HaCaT}$ cells, a minimal value of $28.69 \%$ was recorded, compared to stressed cells (100\%) (Figure 5b). In addition, the ROS production values decreased in a dose-dependent manner in L929 cells and the level recorded at a concentration of $120 \mu \mathrm{g} / \mathrm{mL}$ FBBP $(8.22 \%)$ was similar to that registered for AA treatment $(7.81 \%)$, a known antioxidant agent used in cosmetic products. A slower decrease was observed in $\mathrm{HaCaT}$ cells, indicating a weaker antioxidant effect of the tested concentrations of FBBP.

The same model was used to evaluate FBBP capacity to prevent lipid peroxidation chain reaction using thiobarbituric acid reactive substances (TBARS) assay. The results show that oxidative stress has induced a significant $(p<0.05)$ increase of intracellular MDA concentration in L929 cells from 461 to $777 \mu \mathrm{M} / \mathrm{g}$ protein, indicating lipid fragments generation (Figure 5a). Pretreatment of L929 cells with $60 \mu \mathrm{g} / \mathrm{mL}$ FBBP could not hinder the process, but, at a concentration of $120 \mu \mathrm{g} / \mathrm{mL}$ FBBP, a significant $(p<0.05)$ decrease of MDA concentration ( $603 \mu \mathrm{M} / \mathrm{g}$ protein) was registered, close to the value registered in case of AA treatment (584 $\mu \mathrm{M} / \mathrm{g}$ protein). In HaCaT cells, high MDA level was observed in FBBP-treated similar to that in oxidative stressed cells, indicating low protection of keratinocytes (Figure 5b).

Exposure to UV light, as an exogenous factor, and the limited endogenous antioxidant system lead to increased intracellular level of ROS and reactive nitrogen species involved in redox signaling and oxidative stress in skin cells [43]. Therefore, the mechanism of photochemical formation of oxidizing agents (hydrogen peroxide- $\mathrm{H}_{2} \mathrm{O}_{2}, \mathrm{HO}$ radical, superoxide anion, singlet oxygen and peroxynitrite), which react with polyunsaturated fatty acids, consists of a cascade of lipid peroxidation reactions resulting in the formation of lipid hydroperoxides, followed by their fragmentation into reactive aldehydes with impact on altering proteomic and genomic targets and, finally, producing cellular lesions (cell membrane) or cell death by apoptosis and necrosis [44].

Photoprotection and anti-aging cosmeceuticals based on natural antioxidant compounds have recently been developed to prevent skin damage by topical application or oral administration. Several studies demonstrated that fish protein hydrolysates isolated mainly from skin and muscle could represent potential sources of antioxidant bioactive peptides [45], but few analyzed fish bone peptides effect on ROS cellular level in skin cells (fibroblasts and keratinocytes). A recent study reported that fish collagen peptides isolated from redlip croaker scales by neutrase digestion, having a MW of 733-886 Da, allowed the decrease of ROS level in oxidative damaged HepG2 hepatocyte carcinoma cells [46]. The results are similar to those found in our study, indicating the antioxidant activity of fish bone peptides is as a result of their reaction with ROS species based on a hydrogen atom transfer mechanism. 


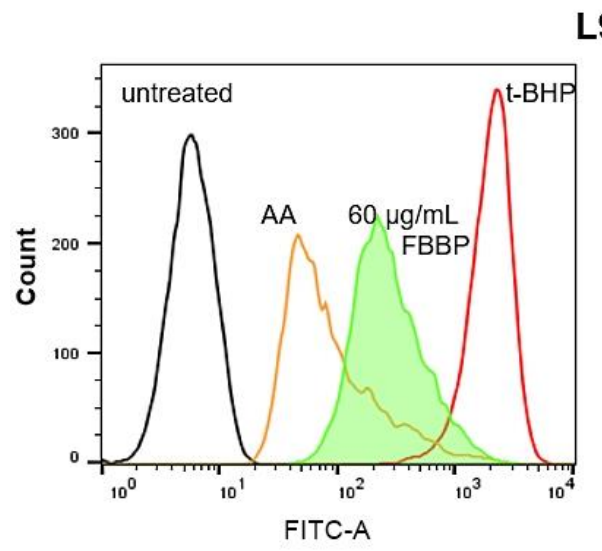

L929 cells

a
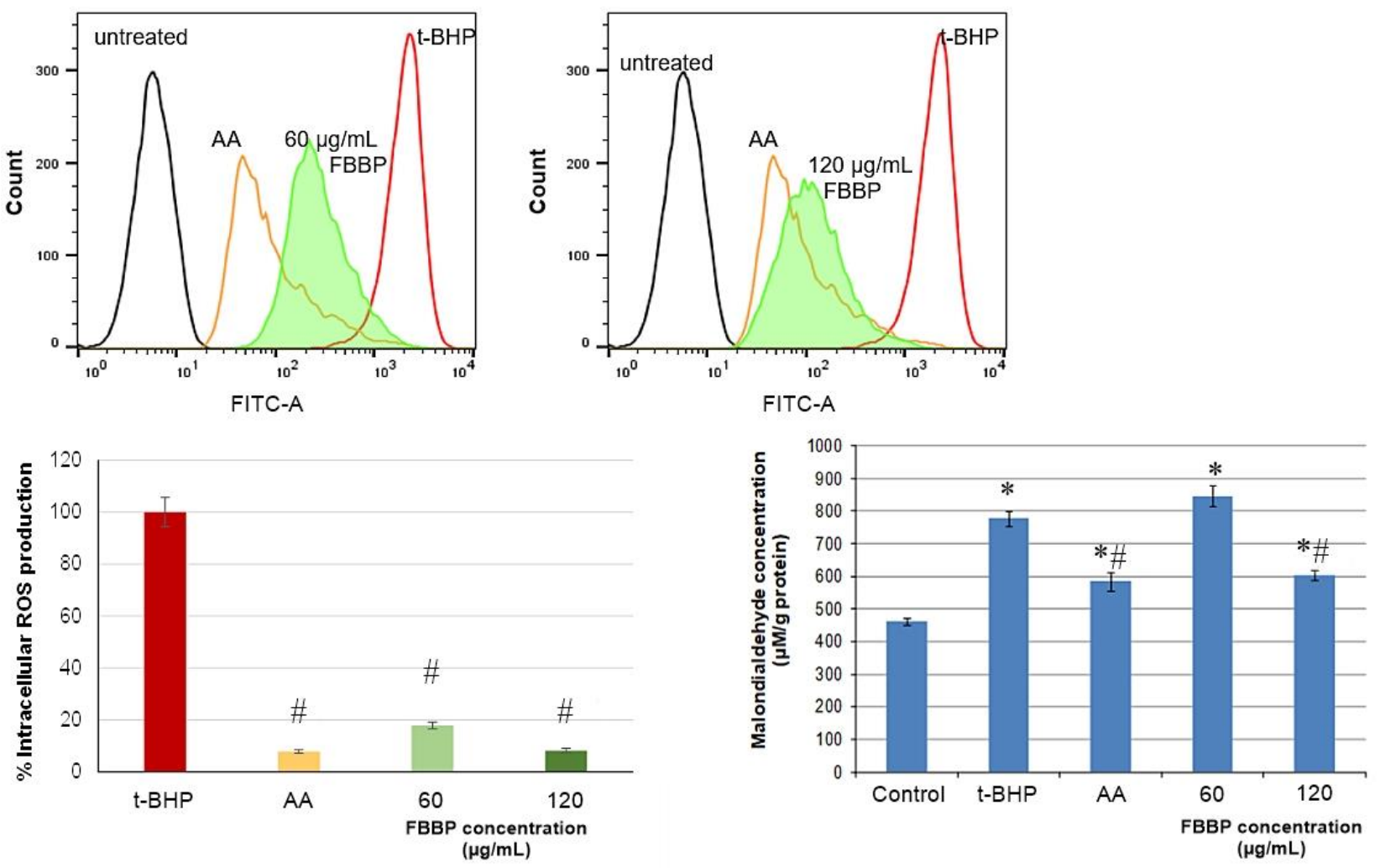

HaCaT cells
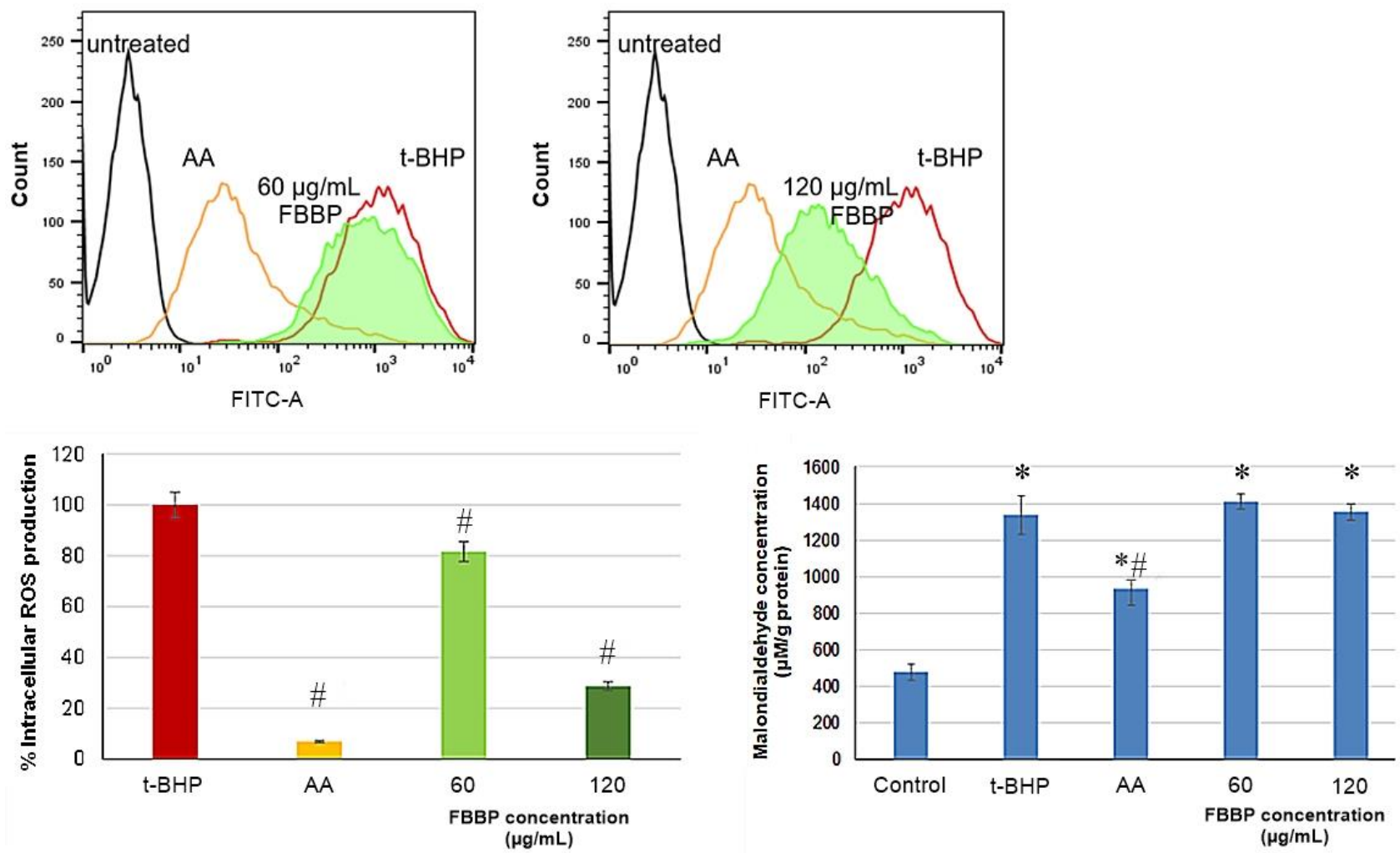

Figure 5. Level of intracellular ROS and MDA production in tert-butyl hydroperoxide (t-BHP) oxidative stress model of L929 (a) and HaCaT (b) cells treated with different concentrations of FBBP and AA, determined by flow cytometry and TBARS assay, respectively. ${ }^{*} p<0.05$, compared to untreated control; ${ }^{\#} p<0.05$, compared to t-BHP-stressed control. 
In regard to the fish peptides' effect on lipid peroxidation, the same study reported their capacity to significantly reduce the MDA level in oxidative stressed HepG2 cells, indicating their protection role by lowering the oxidative stress injury [46]. In vivo studies on mice indicated a slight increase of MDA plasma level within the physiological range of concentrations after oral administration of marine collagen peptides from deep sea fish skin, but this was discussed as beneficial for the stimulation of collagen synthesis, adenosine triphosphate (ATP) storage and sebum production, in view of skin properties improvement [23]. Other studies reported that gelatin peptides obtained from salmon skin enabled significant decrease of plasma and skin level of MDA in UV-irradiated mice, indicating their capacity to inhibit lipid peroxidation and to repair photoaged skin [47]. Oral administration of collagen hydrolysate obtained from carp skin improved collagen, hyaluronic acid and antioxidative activity in UV-photoaged mice, in correlation to their MW decrease [13].

All these data indicate that FBBP isolated in the present study showed the capacity to intervene in redox processes by reduction of the oxidative stress in skin cell cultures, especially in fibroblasts, which took place through significant decrease of the ROS level and, to a lesser extent, of the lipid peroxidation. Thus, FBBP could represent natural antioxidant ingredients of cosmeceutical formulations, ensuring photoprotection in stressed skin cells.

\subsection{Effect of FBBP on Pro-Inflammatory Cytokines Production in THP-1-Derived Macrophages}

In the present study, THP-1-derived macrophages inflamed by lipopolysaccharide (LPS) treatment served as in vitro experimental model for the evaluation of the antiinflammatory activity of FBBP preparation. The level of TNF- $\alpha$ and interleukin 1 beta (IL-1 $\beta$ ) pro-inflammatory cytokines secretion in LPS-stimulated macrophages cultivated in the presence of FBBP was determined by enzyme-linked immunosorbent assay (ELISA). The results show that LPS treatment significantly $(p<0.05)$ increased TNF- $\alpha$ and IL-1 $\beta$ production by $770 \%$ and $155 \%$, respectively, compared to the untreated control (Figure 6). In response to FBBP treatment, the level of TNF- $\alpha$ pro-inflammatory cytokine significantly $(p<0.05)$ decreased in a dose-dependent manner by $15 \%$ and $40 \%$, at increasing concentrations of 60 and $120 \mu \mathrm{g} / \mathrm{mL}$, respectively (Figure $6 \mathrm{a}$ ). In turn, IL-1 $\beta$ level was significantly $(p<0.05)$ lowered by FBBP treatment, compared to the inflamed control, but in a range of $18-20 \%$ (Figure $6 \mathrm{~b}$ ).

Skin exposure to UV radiation, primarily to UVB wavelengths, could induce erythema and inflammatory response in epidermis and upper dermis, as documented by histological observations [48]. The cascade of inflammatory mediators' synthesis and ROS formation and Langerhans cells decrease define the mechanisms leading to sunburn, in short exposure, or skin photoaging and carcinogenesis, in chronic exposure, triggering the innate immune response [49]. The experimental model used in the present study was based on LPS-inflamed macrophages, knowing that LPS component of the outer membrane of Gram-negative bacteria could act as an endotoxin, inducing septic shock syndrome and stimulating the synthesis of inflammatory mediators, such as pro-inflammatory cytokines (TNF- $\alpha$, IL-1 $\beta$ and IL-6), nitric oxide, prostanoids and leukotrienes. TNF- $\alpha$ is the main cytokine involved in systemic inflammation, especially in the acute phase reaction, with an important role in immune cells regulation, while IL- $1 \beta$ is involved in cell proliferation, differentiation and apoptosis. In previous studies, LPS was recognized by macrophage cells as a pathogen-associated molecular pattern and involved in upregulation of cell surface Toll-like receptor 4 (TLR4) after specific binding [50]. The internalization of TLR4 in endosomes led to activation of the immune response via TIR-domain-containing adapterinducing interferon- $\beta$ (TRIF)-dependent signaling pathway, controlled by CD14 membrane protein [51]. Previous reports showed that peptides could inhibit TLR4 endocytosis and the triggered cascade signaling pathways via phosphorylation of mitogen-activated protein kinases (MAPK) and nuclear translocation of nuclear factor kB (NF-kB) pathway components in LPS-stimulated RAW264.7 cells [52]. An antioxidant peptide isolated from O. livida 
secretion inhibited in vivo erythema inflammation in UVB-irradiated mice skin, providing photoaging potential [39].
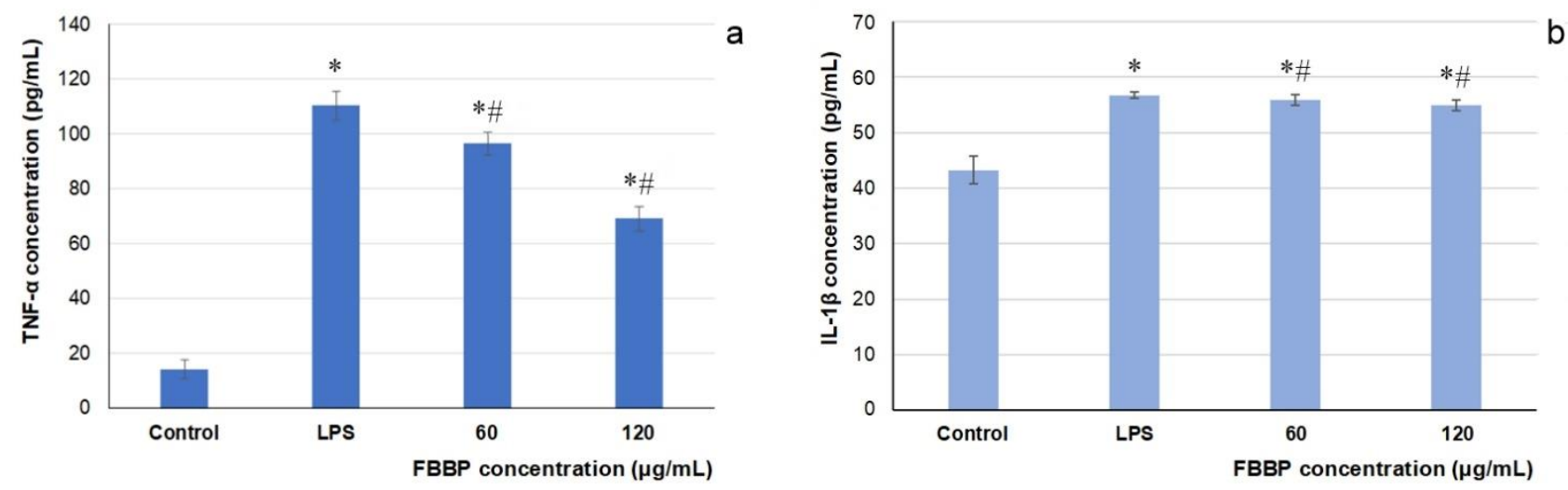

Figure 6. Secretion of TNF- $\alpha$ (a) and IL-1 $\beta$ (b) pro-inflammatory cytokines in LPS-inflamed THP-1 macrophages pretreated with different concentrations of FBBP, determined by ELISA assay at $24 \mathrm{~h}$ of cultivation. ${ }^{*} p<0.05$, compared to untreated cells (control); ${ }^{\#} p<0.05$, compared to LPS-inflamed cells.

The present study offered new scientific data that demonstrated, for the first time, the anti-inflammatory activity of FBBP in LPS-treated THP-1-derived macrophage cells by significantly attenuation of pro-inflammatory cytokines production, especially of TNF- $\alpha$ level, which could offer protection against inflammatory response in UVB-exposed skin.

\subsection{Effect of FBBP on Melanogenesis in UVB-Irradiated Mel-Juso Cells}

In the present study, the cytocompatibility of FBBP in Mel-Juso melanoma cells was first evaluated by MTT assay. The results show that FBBP were non-cytotoxic (cell viability $>80 \%$ ) on the entire tested range of concentrations $(30-1500 \mu \mathrm{g} / \mathrm{mL}$ ) at $24 \mathrm{~h}$ of cultivation (Figure $7 \mathrm{a}$ ). At $72 \mathrm{~h}$ of cultivation, FBBP were cytocompatible in the same range of concentrations, except for the concentration of $1500 \mu \mathrm{g} / \mathrm{mL}$, which decreased the cell viability to $75 \%$. Two concentrations of FBBP were selected for further testing, $250 \mu \mathrm{g} / \mathrm{mL}$ giving the highest cell viability (118\%) and $1000 \mu \mathrm{g} / \mathrm{mL}$ as the highest cytocompatible value.

In the model of UVB-irradiated Mel-Juso cells, the intracellular melanin secretion was stimulated by 3.9-fold after three-day exposure to UVB radiation (Figure $7 \mathrm{~b}$ ). The effect of FBBP pretreatment on the suppression of UVB-induced melanin synthesis was determined by melanin production measurement. Thus, the melanin content significantly $(p<0.05)$ decreased by $51 \%$ and $~ 55 \%$ at concentrations of 250 and $1000 \mu \mathrm{g} / \mathrm{mL}$ FBBP, respectively, compared to UV-treated control (Figure $7 \mathrm{~b}$ ). Similarly, AA treatment lowered the melanin secretion by $42 \%$. In addition, FBBP treatment significantly $(p<0.05)$ inhibited tyrosinase activity by $52 \%$ at a concentration of $250 \mu \mathrm{g} / \mathrm{mL}$ and $74 \%$ at $1000 \mu \mathrm{g} / \mathrm{mL}$, reaching the normal level of control cells, also observed in AA-treated cells (Figure 7c).

Antioxidants, such as AA, hydroquinone, arbutin or niacinamide, were used as melanogenesis inhibitory agents, but safety was discussed related to the used concentrations [53]. It was previously reported that certain peptides containing Arg in combination with Ala, Val or Leu were strongly bound to tyrosinase and inhibited its key activity in melanin production process [54]. This observation could also explain the downregulation of melanogenesis by peptides from FBBP preparation obtained in the present study by papain digestion. In vivo studies examined oral administration of fish scale collagen peptides to women and reported their ability to decrease the area of UV spots [55]. Melanocytes response to skin inflammation after UVB exposure can occur through hyperpigmentation, especially on the face, creating solar lentigo (sun spots) and causing distress to the affected individuals [56]. Recently, melanogenesis process was showed to be associated with innate immune response level, sharing the same TLR modulation and MAPK signaling 
pathways discussed in relation to the anti-inflammatory activity [57]. These mechanisms could probably explain the relevant findings in the present study showing the capacity of FBBP to suppress cellular melanin biosynthesis in UVB-exposed cells and their depigmenting effect, similar to that of AA. In this context, FBBP could be further tested as natural depigmentation compounds and potential use in photoprotective formulations.
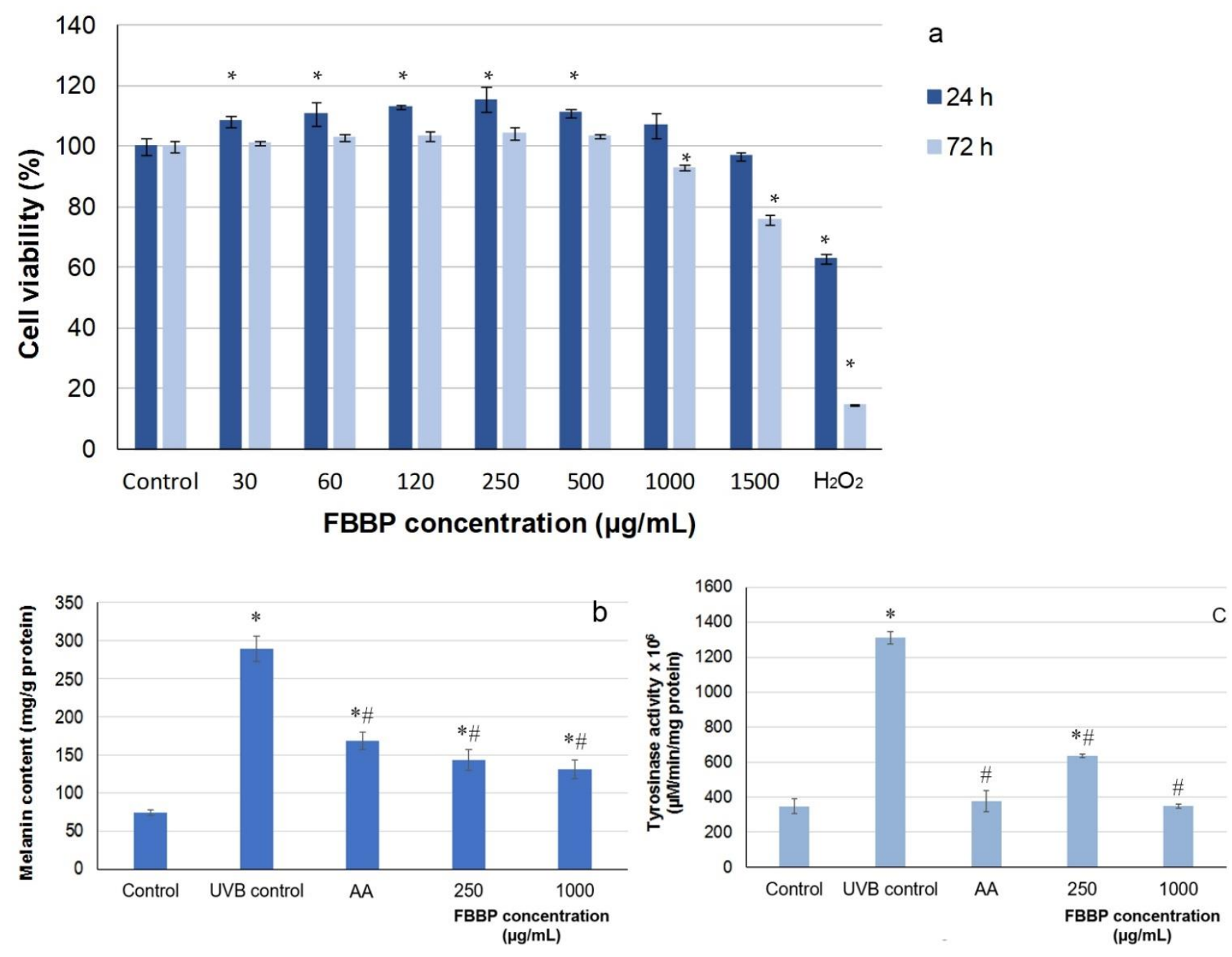

Figure 7. Cell viability of Mel-Juso melanoma cells cultivated in the presence of different concentrations of FBBP, for 24 and $72 \mathrm{~h}$, determined by MTT assay (a). The effect of FBBP and AA on melanin content (b) and tyrosinase activity (c) in UVB-irradiated Mel-Juso melanoma cells. ${ }^{*} p<0.05$, compared to untreated control; ${ }^{\#} p<0.05$, compared to UVB control.

Due to all these beneficial properties verified within different in vitro experimental models, FBBP preparation might be useful as bioactive ingredient to develop novel cosmeceuticals intended to exert both cosmetic and therapeutic effect on skin cells function during UV exposure.

\subsection{Separation of FBBP Fractions and Identification of Antioxidant Peptides}

During cation exchange chromatography, FBBP preparation was separated into four peaks (I-IV), two collected at low ionic strength and two during the gradient elution with increasing $\mathrm{NaCl}$ concentrations (0.2-1 M) (Figure 8), indicating the presence of peptides with variable $\mathrm{pI}$. Thus, peptides with low $\mathrm{pI}$ values carried a net negative charge at $\mathrm{pH} 7$ and eluted first, followed by those with $\mathrm{pI}$ close to 7 , while peptides with high $\mathrm{pI}$ values carried a net positive charge, bound to the resin and eluted at high salt concentration. 


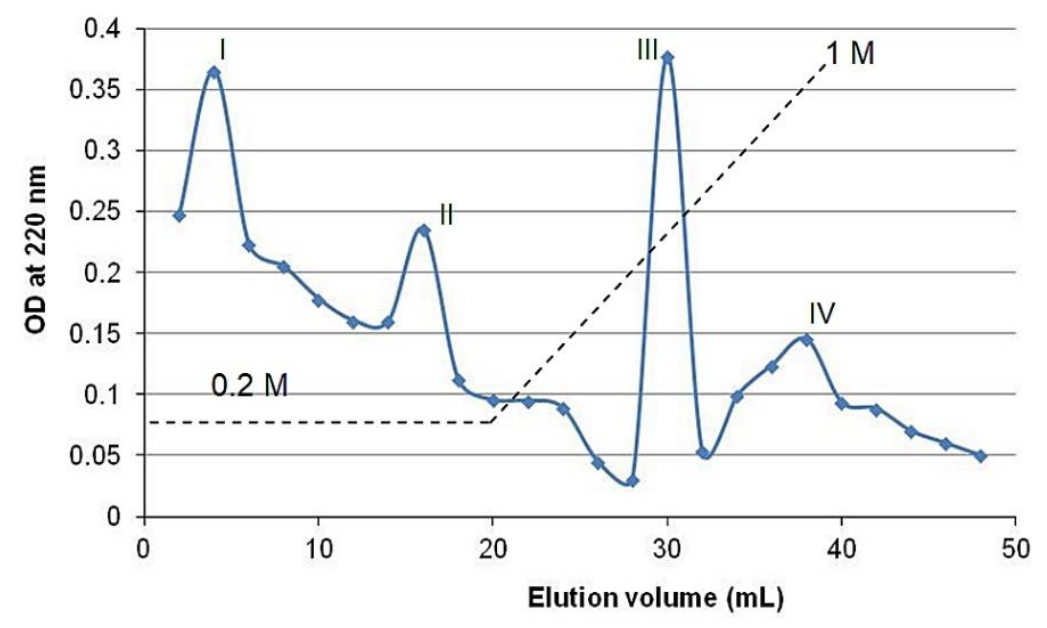

Figure 8. Ion exchange chromatography of FBBP on CM-Sephadex using $0.2-1 \mathrm{M} \mathrm{NaCl}$ gradient.

In addition, the fractions were analyzed for their capacity to scavenge synthetic free radicals of 2,2'-azino-bis(3-ethylbenzothiazoline-6-sulfonic acid) (ABTS) and hydroxyl (HO) radicals also present in the biological environment. The results showed that peptides from Fractions III and IV had significantly $(p<0.05)$ higher antiradical activities, compared to those of peptides from Fractions I and II, in both experimental models (Table 2). Similar studies analyzed and reported the antioxidant activity of various enzymatic fish bone hydrolysates, excepting silver carp (Table 1).

Table 2. The antiradical activity of ion exchange chromatography fractions of bioactive peptides from H. molitrix bones determined against ABTS and HO radicals. The sequence, molecular weight (MW) and pI of peptides identified in the UniProt database matching the mass spectrum peaks. Reprinted from ref. [17].

\begin{tabular}{cccccc}
\hline Sample & $\begin{array}{c}\text { ABTS Scavenging } \\
\text { Activity } \\
\text { (mM Trolox Equiv./g } \\
\text { Protein) }\end{array}$ & $\begin{array}{c}\text { HO Scavenging } \\
\text { Activity } \\
\text { (mM Trolox Equiv./g } \\
\text { Protein) }\end{array}$ & Peptide Sequence & $\begin{array}{c}\text { MW } \\
\text { (Da) }\end{array}$ & $\begin{array}{c}\text { pI } \\
\text { Fraction I }\end{array}$ \\
& $2.85 \pm 0.78$ & $18.68 \pm 1.06$ & $812-G E A G D N G A K-820$ & 817.81 & 4.37 \\
Fraction II & $2.73 \pm 0.14$ & $15.38 \pm 1.84$ & 337-GEVGPQGAR-345 & 869.93 & 6.00 \\
Fraction III & $57.15 \pm 3.53^{*, \#}$ & $294.54 \pm 10.48^{*}, \#$ & $423-$ GPPGDAGRAGEPGLVGAR-440 & 1633.78 & 6.07 \\
Fraction IV & $16.55 \pm 1.95 * \#$ & $80.37 \pm 6.34^{*, \#}$ & 251-GHRGFSGLDGAK-262 & 1201.31 & 8.75 \\
\hline
\end{tabular}

The values are expressed as mean \pm standard deviation (SD) $(n=3) .{ }^{*} p<0.05$, compared to fraction I; ${ }^{\#} p<0.05$, compared to fraction II.

Fourteen bioactive peptides were identified in FBBP preparation, in a previous study, by matching the peaks of matrix assisted laser desorption ionization-time of flight (MALDITOF) mass spectrum, corresponding to 0-3000 mass-to-charge ratios $(\mathrm{m} / \mathrm{z})$, and the amino acid sequences provided by simulated papain cleavage of type I collagen, the most abundant protein in bone [17]. In the present study, we correlated the calculated MW and isoelectric point $(\mathrm{pI})$ values of the collagenic peptides ranging $0-2000 \mathrm{~m} / \mathrm{z}$ and presenting the characteristic -Gly-X-Y- repetitive sequence, to the chromatography data, in particular the ion exchange and RP-HPLC results, as well as to their antiradical activity. Five collagenic bioactive peptides consisting of 9-21 amino acid residues were identified and presented the following properties: MW ranging $817.81-1874.01 \mathrm{Da}$ and $\mathrm{pI}$ ranging 4.37-9.51. The peptides sequences are given in Table 2, according to their increasing $\mathrm{pI}$ and likely elution during ion exchange chromatography. Acidic amino acids (Glu-E, Asp-D) frequently appeared after Gly residue $(\mathrm{G})$ in the hydrophobic sequences of Pro (P), Ala and Val, while basic amino acids (Arg-R and Lys-K) were found at the C-terminus of peptides. This was in accordance with the documented observation that papain cleaves the protein chain at Arg or Lys residues that are preceded by a hydrophobic amino acid from the fol- 
lowing Ala (A), Val (V), Leu (L), Ile (I), Phe (F), Trp (W) and Tyr (Y), but does not cleave the peptide bonds formed by Arg or Lys residues followed by Val residues [58]. The peptides corresponding to Fractions III and IV had the sequences GHRGFSGLDGAK (1201.31 Da) and GEPGAAGGRGPPGERGAPGAR (1874.01 Da), respectively, and presented the highest antioxidant activity.

All these analyses have shown for the first time that papain enzymatic hydrolysis of $H$. molitrix bone waste promoted the formation of antioxidant peptides with low MW consisting mainly of hydrophobic, collagen-characteristic and charged (acidic and basic) amino acids.

The antioxidant activity of fish peptides has lately been discussed in relationship to their amino acid composition and the derived hydrophilic/hydrophobic character, which played an important role in their bioactivity [59]. Thus, Gly residue was frequently encountered in collagen molecule, as every third amino acid (33\% of its composition), providing great flexibility to peptide skeleton and the ability to quench unpaired radicals or electrons through the hydrogen atom [60]. Moreover, the high content of hydrophobic amino acids, such as Pro, Ala, Leu, Ile and Val, in collagen-derived peptides was reported to enhance the radical scavenging activity [61]. Hydrophobic sequences could also interact with fatty acid chains, increase their lipid solubility and accessibility to hydrophobic sites, thus intervening in the complex process of lipid peroxidation [62]. Other hydrophobic amino acids with aromatic side chain, such as Tyr, Phe and Trp, and aliphatic side chain, such as Met, could also regulate this process due to their metal chelating capacity, but they were poorly found in collagen molecule [63]. In turn, hydrophilic peptides containing acidic and basic amino acids with electrically charged side groups $\left(\mathrm{COO}^{-}\right.$and $\left.\mathrm{NH}_{3}{ }^{+}\right)$ had increased solubility and free radicals quenching ability due to excess of electrons. In previous studies, hydrophilic peptides also showed efficiency in $\mathrm{Fe}^{2+}$ ions binding and decrease of metal ions pro-oxidative capacity in ROS formation systems [64].

The role of specific amino acids position for increased antioxidant activity of foodderived peptides has recently been reported [65]. Thus, C-terminal Arg residue in peptides from seabass skin hydrolysates was found highly correlated to ABTS free radical scavenging capacity, similar to peptides from the present study, while N-terminal Cys (C) improved HO radical scavenging, compared to similar synthetic tripeptides with sequence permutation. Other studies found that Val or Leu end location, corroborated with conformational characteristics of the peptide molecules containing Pro, His or Tyr, increased the potential to act as antioxidant agents [66].

Besides peptides composition and sequence, their size was reported as an important parameter related to the antioxidant activity [67]. It was showed that low MW bioactive peptides of 2-10 amino acids have exerted better ROS scavenging activities, compared to those of polypeptides from which they derived because the small size favored a more efficient interaction with free radicals [61].

All these data indicate that peptidic fractions isolated from silver carp bones and the identified bioactive peptides with specific composition, sequence and amphiphilic character might act synergically with organic/inorganic UV filters from sunscreens to complement UV absorption with antiradical activity.

\section{Materials and Methods}

\subsection{Preparation of Bioactive Peptides from Fish Bone Tissue}

Silver carp headless frames were supplied on ice by a local fishery (Tulcea, Romania). The preparation of bioactive peptides was performed by papain treatment and centrifugal ultrafiltration. Briefly, the bone tissue (200 g) was minced and homogenized with distilled water, in a weight ratio of $1: 1$, using a knife homogenizer. Then, bone tissue decalcification was performed in a solution of $1 \%$ ethylene glycol-bis( $\beta$-aminoethyl ether)- $\mathrm{N}, \mathrm{N}, \mathrm{N}^{\prime}, \mathrm{N}^{\prime}$ tetraacetic acid (EGTA) in $0.05 \mathrm{M}$ Tris buffer, $\mathrm{pH} 7$ by stirring at room temperature for $8 \mathrm{~h}$ and centrifugation at $10,000 \times \mathrm{g}$ for $30 \mathrm{~min}$. For delipidation, the paste was mixed with $200 \mathrm{~mL}$ of $0.05 \mathrm{M}$ Tris buffer and incubated at $55^{\circ} \mathrm{C}$ for $4 \mathrm{~h}$ and at $90^{\circ} \mathrm{C}$ for $15 \mathrm{~min}$. The 
mixture was kept at $4{ }^{\circ} \mathrm{C}$ overnight and then centrifuged at $10,000 \times g$ for $20 \mathrm{~min}$ to remove the upper layer.

Enzymatic hydrolysis was carried out in a water bath by paste incubation in $4 \%$ papain solution, $\mathrm{pH} 5.5$, in a weight ratio of $25: 1$, at $55^{\circ} \mathrm{C}$, for $6 \mathrm{~h}$. At the end of the incubation, the solution was heated at $100{ }^{\circ} \mathrm{C}$ for $5 \mathrm{~min}$ to inactivate the enzyme. Subsequently, the solution was cooled at room temperature and centrifuged at $10,000 \times g$ for $30 \mathrm{~min}$. The supernatant representing a solution of FBH was subjected to centrifugal ultrafiltration at $7500 \times g$, for 25 min using filter units with cellulose membranes of $3000 \mathrm{Da}$ MW cutoff (Amicon, Merck, Darmstadt, Germany). The isolated permeate representing the solution of FBBP was partly stored at $-20{ }^{\circ} \mathrm{C}$ until analysis and partly concentrated in a rotary evaporator (Laborota-4000, Heidolph, Schwabach, Germany) and then lyophilized in a Christ freeze-dryer (Germany), yielding a yellowish powder. The protein content was determined by bicinchoninic acid (BCA) assay using a standard curve built with gelatin type A (Sigma) as standard protein $(0-2 \mathrm{mg} / \mathrm{mL})$.

\subsection{Determination of MW Distribution}

\subsubsection{Size Exclusion Chromatography}

Samples of FBH and FBBP were loaded onto a Sephadex G-75 column $(1 \times 27 \mathrm{~cm})$ and the elution was performed with distilled water, $\mathrm{pH} 7$, at a flow rate of $0.5 \mathrm{~mL} / \mathrm{min}$. Fractions of $2 \mathrm{~mL}$ were collected and the optical density (OD) was recorded at $220 \mathrm{~nm}$ using a V650 UV-VIS spectrophotometer (Jasco, Tokyo, Japan). The high absorbance fractions were pooled, lyophilized and analyzed by ion exchange chromatography. Standards of known MW (bacitracin, insulin, cytochrome $\mathrm{c}$ and albumin) were eluted in the same conditions to build a calibration curve.

\subsubsection{RP-HPLC Analysis}

RP-HPLC analysis of FBBP sample was performed on an Agilent 1200 HPLC system equipped with quaternary pump, thermostated autosampler and diode array detector (Agilent, Santa Clara, CA, USA), using a Europa C18 peptide column (4.6 mm i.d. $\times 150 \mathrm{~mm}$ length), $120 \AA$ (Teknokroma, Barcelona, Spain). A volume of $10 \mu \mathrm{L}$ sample was injected and the elution was carried out in a mobile phase (A, pure water containing $0.1 \%$ trifluoroacetic acid; $\mathrm{B}$, acetonitrile containing $0.08 \%$ trifluoroacetic acid) using a linear gradient of $0-60 \% \mathrm{~B}$ at a flow rate of $1 \mathrm{~mL} / \mathrm{min}$ and temperature of $37^{\circ} \mathrm{C}$ for $30 \mathrm{~min}$. The OD was measured at 218 and $280 \mathrm{~nm}$.

\subsection{Determination of UV Absorption Factor}

UV absorption capacity of peptide sample was evaluated by UV spectroscopy, according to "UV shield factor calculation" software (Jasco, Japan) instructions. Lyophilized sample $(6 \mathrm{mg})$ was suspended in $1 \mathrm{~mL}$ of distilled water and the UV spectra of serially diluted sample were recorded at a V-650 spectrophotometer (Jasco, Japan). The UV absorption factor was calculated by reporting to a default value of 100 on each UVA, UVB and UVC domain using the dedicated software. A control of commercial SPF 6 lotion was similarly analyzed. The samples were analyzed in triplicate.

\subsection{In Vitro Cytocompatibility in Normal and Irradiated Skin Cells \\ 3.4.1. In Vitro Cytocompatibility Model in Normal Cells}

Mouse fibroblasts from NCTC clone L929 cell line (ECACC) were seeded at a density of $4 \times 10^{4}$ cells $/ \mathrm{mL}$ in 96-well plates and cultured in Minimum Essential Medium (MEM) supplemented with $10 \%$ fetal bovine serum (FBS) and $1 \%$ mixture of antibiotics (penicillinstreptomycin-neomycin-PSN), at $37^{\circ} \mathrm{C}$ in $5 \% \mathrm{CO}_{2}$ humid atmosphere, for $24 \mathrm{~h}$. Human keratinocytes from HaCaT cell line (ECACC) were seeded at a density of $5 \times 10^{4}$ cells $/ \mathrm{mL}$ in 96-well plates and cultured in Roswell Park Memorial Institute (RPMI) 1640 supplemented with $10 \% \mathrm{FBS}$ and $1 \%$ PSN, in standard conditions, for $24 \mathrm{~h}$. For the experiments, the culture medium was replaced with fresh culture medium supplemented with FBS, containing 
FBBP concentrations ranging $10-1500 \mu \mathrm{g} / \mathrm{mL}$ and cell cultivation continued in standard conditions, for $48 \mathrm{~h}$. Cells cultivated in the culture medium without sample served as negative control, while cells treated with $10 \mu \mathrm{g} / \mathrm{mL} \mathrm{H}_{2} \mathrm{O}_{2}$ served as positive control that induced cell necrosis. Cells treated with $15 \mu \mathrm{g} / \mathrm{mL}$ AA, a known antioxidant used in cosmetics was used as control with stimulative effect on cell proliferation. The experiments were performed in triplicate.

\subsubsection{In Vitro Cytoprotective Model in UVB-Irradiated Cells}

For the irradiation experiment, the same cell cultures (L929 and HaCaT) and treatment protocol were performed as described above but using a density of $1 \times 10^{5}$ cells $/ \mathrm{mL}$ in $35 \mathrm{~mm}$ Petri dishes. After FBBP treatment for $24 \mathrm{~h}$, the cells were irradiated using a VL-6 LM UV lamp with a maximum energy at $312 \mathrm{~nm}$ (UVB range) for $60 \mathrm{~s}\left(127 \mathrm{~mJ} / \mathrm{cm}^{2}\right)$. Before UV exposure, the culture medium was harvested, replaced with PBS and irradiation was performed in the laminar hood to preserve cell sterility and to avoid overheating. After irradiation, the harvested medium containing FBBP was added over the cells and cultivation continued for $24 \mathrm{~h}$ in standard conditions. The cell viability was evaluated by MTT assay, as described above. The experiments were performed in triplicate. Scheme of in vitro experimental models of FBBP cytocompatibility in normal conditions and cytoprotection in UVB-irradiated cells is presented in Figure 9.

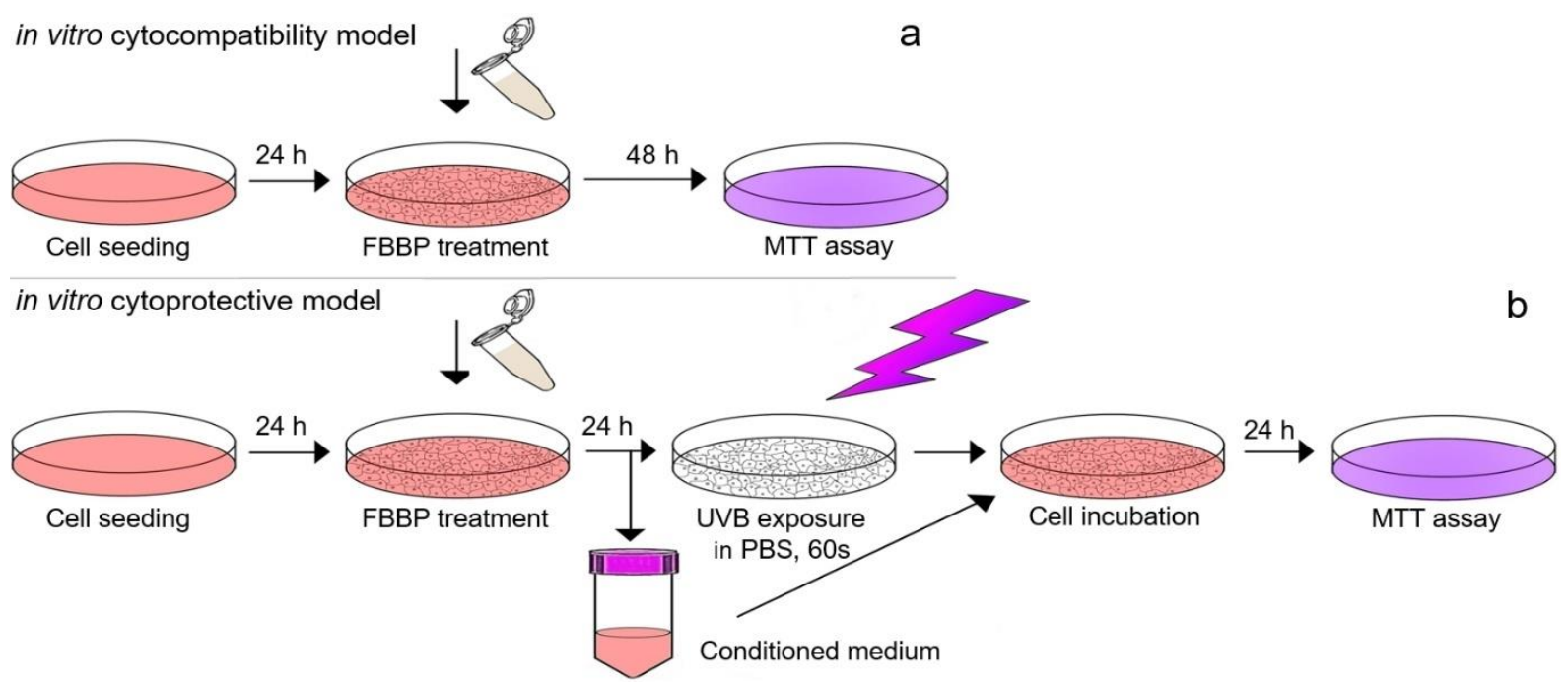

Figure 9. Schematic representation of in vitro experimental models developed for FBBP cytocompatibility testing in normal conditions (a) and cytoprotection in UVB-irradiated cells (b).

\subsubsection{Cell Viability Assay}

MTT assay was used for FBBP cytocompatibility testing according to the international standard ISO 10993-5/2009 based on the reaction of yellow MTT with mitochondrial dehydrogenases from the metabolically active cells through dihydronicotinamide adenine dincleotide (NADH) reduction and formation of purple insoluble formazan crystals, as previously described [68]. At the end of cells incubation, the culture medium was replaced with $100 \mu \mathrm{L}$ MTT solution in MEM $(0.25 \mathrm{mg} / \mathrm{mL})$ and the plate was incubated in $5 \% \mathrm{CO}_{2}$ atmosphere, at $37^{\circ} \mathrm{C}$, for $3 \mathrm{~h}$. Then, the MTT solution was replaced with isopropyl alcohol to solubilize the formazan crystals by gentle shaking, for $15 \mathrm{~min}$. The OD was measured in each well at a wavelength of $570 \mathrm{~nm}$ using a Spectrostar nano microplate reader (BMG Labtech, Germany). The values were directly proportional to the number of viable cells.

\subsubsection{Cell Morphology Observations by Light Microscopy}

Cell morphology of FBBP-treated cultures with and without UVB irradiation was observed in a parallel experiment, in the same conditions as described above. At the end of 
the incubation, the cells were examined and phase contrast micrographs were acquired at an AxioStar Plus microscope equipped with a digital camera (Carl Zeiss, Jena, Germany).

\subsection{Determination of Antioxidant Activity in Skin Cell Cultures}

\subsubsection{Determination of Intracellular ROS Production}

The effect of FBBP on intracellular ROS production has been evaluated in an experimental model of oxidative stress induced in skin cells culture, as previously described [69]. L929 cells were seeded at a density of $5 \times 10^{4}$ cells $/ \mathrm{mL}$ and HaCaT cells at a density of $6 \times 10^{4}$ cells $/ \mathrm{mL}$ in 12-well culture plates and cultivated in MEM, in standard conditions, for $24 \mathrm{~h}$. Adhered cells were incubated with fresh medium containing 60 and $120 \mu \mathrm{g} / \mathrm{mL}$ FBBP, respectively, at $37{ }^{\circ} \mathrm{C}$ in humidified atmosphere with $5 \% \mathrm{CO}_{2}$ for $24 \mathrm{~h}$, and, then, cells were treated with $50 \mu \mathrm{M}$ t-BHP, for $30 \mathrm{~min}$.

The cell permeant fluorogenic dye $2^{\prime}, 7^{\prime}$-dichlorofluorescin diacetate (DCFH-DA) was used to measure ROS production at cellular level. Upon reaction with free radicals, formation of DCF fluorescent product was monitored. The cells treated as above were incubated with $10 \mu \mathrm{M}$ DCFH-DA for $30 \mathrm{~min}$ and analyzed using BD LSR II flow cytometer (Becton Dickinson, Franklin Lakes, NJ, USA). Acquired histograms were processed to calculate ROS production (\%) in correlation to the fluorescence intensity using FlowJo and Diva software. Cells incubated in normal medium and cells pre-treated with $12 \mu \mathrm{M}$ AA were processed in similar conditions and served as controls.

\subsubsection{Determination of Lipid Peroxidation by TBARS Assay}

Using the same model of oxidative stressed skin cells treated with FBBP as described above, the level of lipid peroxidation was analyzed by determination of MDA production using TBARS spectrophotometric assay, as previously described [70]. Thus, at the end of the incubation with oxidizing agent, the cells were lysed and the supernatant was mixed with thiobarbituric acid (TBA) reagent, in acid medium, at $95^{\circ} \mathrm{C}$, for $1 \mathrm{~h}$. After centrifugation at $3000 \times g$, for $10 \mathrm{~min}$, the OD of the mixtures containing the MDA-TBA adduct was recorded at $532 \mathrm{~nm}$ using a V-650 UV-VIS spectrophotometer (Jasco). The lysate was also analyzed for protein content by the BCA method. The results were expressed in $\mu \mathrm{M} \mathrm{MDA} / \mathrm{g}$ protein, considering $\varepsilon=1.55 \times 10^{6} \mathrm{M}^{-1} \mathrm{~cm}^{-1}$ for the MDA-TBA complex.

\subsection{Determination of In Vitro Anti-Inflammatory Activity}

The anti-inflammatory activity was evaluated in an experimental model of macrophages derived from human THP-1 leukemic monocyte cells (ATCC), as previously described [71]. Briefly, cells were seeded at a cell density of $1 \times 10^{6}$ cells $/ \mathrm{mL}$ in 24-well plates in RPMI 1640 medium with high glucose content $(4.5 \mathrm{~g} / \mathrm{L})$, supplemented with $10 \%$ FBS and $1 \%$ mixture of antibiotics and incubated in humid atmosphere with $5 \% \mathrm{CO}_{2}$ at $37^{\circ} \mathrm{C}$ for $18 \mathrm{~h}$. After cells differentiation in macrophages by treatment with $100 \mathrm{ng} / \mathrm{mL} 12$-myristate 13-acetate (PMA) for $72 \mathrm{~h}$, the culture medium was replaced with fresh medium containing 60 and $120 \mu \mathrm{g} / \mathrm{mL}$ FBBP, respectively, and incubation continued for $1 \mathrm{~h}$. Then, cells were incubated with $10 \mathrm{ng} / \mathrm{mL}$ LPS to induce inflammation and incubation continued for $24 \mathrm{~h}$. The culture media were harvested and centrifuged at $400 \times g$, for 10 min and TNF- $\alpha$ and IL- $1 \beta$ proinflammatory cytokines production was analyzed using ELISA sandwich kits, according to the manufacturer's protocol (Invitrogen). Cell viability was evaluated by MTT assay. The results were expressed as $\mathrm{pg} / \mathrm{mL}$ after normalization to viable cells. The experiments were performed in triplicate.

\subsection{Analysis of Melanogenesis}

\subsubsection{Cytocompatibility Assay}

The stabilized Mel-JuSo human melanoma cell line was cultured in RPMI culture medium supplemented with $10 \%$ FBS, $1 \%$ non-essential amino acids, $2 \mathrm{mM}$ glutamine, $1 \mathrm{mM}$ sodium pyruvate and $1 \%$ PSN mixture of antibiotics. For experiments, cells were seeded at a density of $4 \times 10^{4}$ cells $/ \mathrm{mL}$ in 96 -well plates and allowed to adhere overnight. 
Then, the medium was replaced with fresh culture medium containing FBBP concentrations in the range of $30-1500 \mu \mathrm{g} / \mathrm{mL}$ and incubation continued in standard conditions for 24 and $72 \mathrm{~h}$. Cell viability was evaluated by MTT assay, as described above. Untreated cells cultivated in standard conditions served as negative control and cells cultivated with $15 \mu \mathrm{g} / \mathrm{mL} \mathrm{H}_{2} \mathrm{O}_{2}$ served as positive control.

\subsubsection{Determination of Melanin Production}

Subconfluent cells were trypsinized, seeded at a density of $4 \times 10^{4}$ cells $/ \mathrm{mL}$ in $35 \mathrm{~mm}$ Petri dishes and incubated in a humid atmosphere with $5 \% \mathrm{CO}_{2}$ for $7 \mathrm{~h}$. Then, 250 and $1000 \mu \mathrm{g} / \mathrm{mL}$ FBBP were added in culture medium, respectively, and incubation continued overnight. Then, cells were irradiated using a VL-6 LM UV lamp at $312 \mathrm{~nm}$, vertically, for $10 \mathrm{~s}\left(21 \mathrm{~mJ} / \mathrm{cm}^{2}\right)$ in three consecutive days. During irradiation, the conditioned medium was replaced with PBS. The intracellular melanin content was measured in cell lysate obtained by treatment with $0.1 \%$ Triton X-100 in Tris-HCl buffer $\mathrm{pH} 7.5$ and centrifugation at $3000 \times g$ and $4{ }^{\circ} \mathrm{C}$ for $10 \mathrm{~min}$, as previously described [72]. The supernatant was harvested for protein content analysis by the BCA assay. The precipitate was dissolved in $300 \mu \mathrm{L}$ $1 \mathrm{~N} \mathrm{NaOH}$ containing $10 \%$ dimethyl sulfoxide by incubation at $80^{\circ} \mathrm{C}$, for $1 \mathrm{~h}$. The OD was measured at $405 \mathrm{~nm}$ using a Spectrostar nano microplate reader (BMG Labtech, Ortenberg, Germany) and the values were normalized to the protein concentration. The results were expressed in $\mathrm{mg}$ melanin/g protein.

\subsubsection{Determination of Tyrosinase Activity}

Using the same model of UVB-irradiated melanocytes treated with FBBP as described above, the cellular tyrosinase activity was evaluated by measuring the 3,4-dihydroxy-Lphenylalanine (L-DOPA) oxidation rate [73]. At the end of the incubation period, cells were lysed and the supernatant was mixed with $2 \mathrm{mg} / \mathrm{mL}$ L-DOPA solution and incubated at $37^{\circ} \mathrm{C}$. The OD was registered at $475 \mathrm{~nm}$ at every $2 \mathrm{~min}$, for $30 \mathrm{~min}$ using a Spectrostar nano microplate reader (BMG Labtech, Germany). Lysis buffer was used as control. The results were calculated as $\mu \mathrm{M} / \mathrm{min}$ and were normalized to the protein concentration determined by the BCA assay.

\subsection{Separation of FBBP Fractions and Antioxidative Peptides Identification \\ 3.8.1. Ion Exchange Chromatography}

FBBP sample was loaded onto a CM-Sephadex C-50 column $(1 \times 7 \mathrm{~cm})$, equilibrated with $0.2 \mathrm{M} \mathrm{NaCl}$ solution. The elution was performed using a volume of $0.2 \mathrm{M} \mathrm{NaCl}$ and then, a linear gradient of $\mathrm{NaCl}$ in the range of concentrations $0.2-1 \mathrm{M}$, at a flow rate of $1 \mathrm{~mL} / \mathrm{min}$. Fractions of $3 \mathrm{~mL}$ were collected and the OD was read at $220 \mathrm{~nm}$ using a V650 UV-VIS spectrophotometer (Jasco, Japan). The high absorbance fractions were pooled, lyophilized and analyzed for antioxidant activity.

\subsubsection{ABTS Free Radicals Scavenging Analysis}

The capacity to scavenge ABTS free radicals was evaluated by Trolox equivalent antioxidant capacity (TEAC) assay [74]. Briefly, the stock solution of $7 \mathrm{mM}$ ABTS containing $2.45 \mathrm{mM}$ potassium persulfate was diluted to reach an OD value of $0.7 \pm 0.02$ at $734 \mathrm{~nm}$ (control). Diluted samples $(100 \mu \mathrm{L})$ were incubated with ABTS reagent $(1 \mathrm{~mL})$ at room temperature in the dark for $10 \mathrm{~min}$. Then, OD of the reaction mixtures was recorded at V-650 UV-VIS spectrophotometer (Jasco, Japan). The percentage of ABTS radical inhibition was calculated using the following formula:

$$
\text { ABTS radicals inhibition }(\%)=\left(\mathrm{OD}_{\text {control }}-\mathrm{OD}_{\text {sample }}\right) / \mathrm{OD}_{\text {control }} \times 100
$$

A calibration curve was built using Trolox, an analog of vitamin E with known antioxidant activity, in the range of concentrations of $0-150 \mu \mathrm{M}$. The antioxidant activity was expressed as $\mathrm{mM}$ Trolox equiv/g protein. All samples were analyzed in triplicate. 


\subsubsection{HO Radicals Scavenging Analysis}

The capacity to scavenge $\mathrm{HO}$ radicals generated by Fenton reaction was determined in a microplate assay, as previously described [75]. Diluted sample $(80 \mu \mathrm{L})$ was mixed with $2 \mathrm{mM} \mathrm{1,10} \mathrm{phenanthroline}(40 \mu \mathrm{L})$ in the wells of a 96-well microplate. Then, $40 \mu \mathrm{L}$ of each $2 \mathrm{mM} \mathrm{FeSO}_{4}$ solution and $0.03 \%(v / v) \mathrm{H}_{2} \mathrm{O}_{2}$ were added into the mixture. The microplate was incubated at $37^{\circ} \mathrm{C}$ in the dark for $1 \mathrm{~h}$ and the OD of the resulting solution was measured at $536 \mathrm{~nm}$ using Spectrostar nano microplate reader (BMG Labtech, Germany). The percentage of HO radical inhibition was calculated using the following formula:

$$
\mathrm{HO} \text { radicals inhibition }(\%)=\left(\mathrm{OD}_{\text {sample }}-\mathrm{OD}_{\text {negative control }}\right) /\left(\mathrm{OD}_{\text {control }}-\mathrm{OD}_{\text {negative control })} \times 100\right.
$$

where negative control replaced the sample with distilled water and the control was replaced $\mathrm{H}_{2} \mathrm{O}_{2}$ with distilled water.

The calibration curve was built using Trolox in the range of concentrations of $0-500 \mu \mathrm{M}$. The antioxidant activity was expressed as $\mathrm{mM}$ Trolox equiv./g protein. All samples were analyzed in triplicate.

\subsubsection{Peptides Identification}

For the identification of collagenic peptides with high antioxidant activity in FBBP preparation, an analysis of correlation between ion exchange chromatography and free radicals scavenging data obtained as described above was performed; the peptides were isolated by MALDI-ToF mass spectrometry analysis in the range of $0-2000 \mathrm{~m} / z$; and their amino acid sequences, $\mathrm{pI}$ and MW were predicted using Uniprot database information, as previously reported [17].

\subsection{Statistical Analysis}

All experiments were carried out in triplicate. The results were expressed as mean value \pm SD for three experiments. Statistical analysis of the data was performed on each pair of interest using two-tailed, paired Student's $t$-test (Office Excel 2010 software). Differences were considered statistically significant at $p<0.05$.

\section{Conclusions}

This study offered an efficient processing approach, easy to scale-up for FBBP isolation from discarded freshwater fish bones and a correlation study of their physicochemically characterization to photoprotective properties, namely UV absorption factor, anti-inflammatory activity and inhibition of intracellular ROS, MDA, melanin production and tyrosinase activity. Evaluation of FBBP in skin cell cultures showed cytocompatibility and cytoprotective properties against UVB-irradiation, good capacity to reduce ROS level and, to a lesser extent, the lipid peroxidation in both L929 fibroblasts and HaCaT keratinocytes. In vitro experiments showed, for the first time, the anti-inflammatory activity of FBBP in LPS-stimulated THP-1-derived macrophages by significantly lowering the TNF- $\alpha$ and IL-1 $\beta$ pro-inflammatory cytokines production. Moreover, FBBP suppressed melanin production in UVB-irradiated Mel-Juso cells through inhibition of tyrosinase activity, a key enzyme involved in melanogenesis. Finally, FBBP fractions with high antiradical activity were separated and identification of collagenic peptides showed sequences of acidic amino acids alternating with hydrophobic ones and ending with basic amino acids, having a MW of 1201.31 and $1874.01 \mathrm{Da}$. All this new scientific evidence strongly suggests that FBBP isolated from discarded H. molitrix bones might have an important impact on skin cells metabolism due to their antioxidant, anti-inflammatory and melanin suppression activity. Future work will envisage the importance of fish peptides beneficial properties in relation to in vivo skin photoaging process. 
Supplementary Materials: The following is available online. Figure S1: Spectra of fish bone bioactive peptides (FBBP) preparation isolated from $H$. molitrix, at different concentrations (a) and commercial SPF6 lotion (control) (b) in UVA, UVB and UVC domains.

Author Contributions: Conceptualization and supervision, O.C. and F.O.; formal analysis, A.I., D.I. and A.-M.S.-G.; data curation, O.C., A.-M.S.-G., A.O. and O.Z.; funding acquisition, I.M. and F.O.; resources, O.C., A.O. and F.O.; writing original draft, A.I., D.I. and A.O.; and review and editing, O.C., O.Z., I.M. and F.O. All authors have read and agreed to the published version of the manuscript.

Funding: This research was supported by the Romanian Ministry of Research and Innovation, CCCDI-UEFISCDI, project No. PN-III-P1-1.2-PCCDI-2017-0569 for study resources and project No. PN-III-P2-2.1-PTE-2019-0181 for resources and publishing fee.

Data Availability Statement: The data presented in this study are available in this article.

Conflicts of Interest: The authors declare no conflict of interest.

\section{References}

1. Falcone, L.M.; Zeidler-Erdely, P.C. Skin cancer and welding. Clin. Exp. Dermatol. 2019, 44, 130-134. [CrossRef] [PubMed]

2. Ciazynska, M.; Olejniczak-Staruch, I.; Sobolewska-Sztychny, D.; Narbutt, J.; Skibinska, M.; Lesiak, A. Ultraviolet radiation and chronic inflammation-Molecules and mechanisms involved in skin carcinogenesis: A narrative review. Life 2021, 11, 326. [CrossRef] [PubMed]

3. Valejo Coelho, M.M.; Apetato, M. The dark side of the light: Phototherapy adverse effects. Clin. Dermatol. 2016, 34, 556-562. [CrossRef]

4. Rinnerthaler, M.; Bischof, J.; Streubel, M.K.; Trost, A.; Richter, K. Oxidative stress in aging human skin. Biomolecules 2015, 5, 545-589. [CrossRef] [PubMed]

5. Parrado, C.; Philips, N.; Gilaberte, Y.; Juarranz, A.; Gonzalez, S. Oral photoprotection: Effective agents and potential candidates. Front. Med. (Lausanne) 2018, 5, 188. [CrossRef] [PubMed]

6. Venkatesan, J.; Anil, S.; Kim, S.K. Marine fish proteins and peptides for cosmeceuticals: A review. Mar. Drugs 2017, 15, 143. [CrossRef]

7. Aguilar-Toalá, J.E.; Hernandez-Mendoza, A.; González-Córdova, A.F.; Vallejo-Cordoba, B.; Liceaga, A. Potential role of natural bioactive peptides for development of cosmeceutical skin products. Peptides 2019, 122, 170170. [CrossRef]

8. Guillerme, J.B.; Couteau, C.; Coiffard, L. Applications for marine resources in cosmetics. Cosmetics 2017, 4, 1-15.

9. Valimaa, A.L.; Makinen, S.; Mattila, P.; Marnila, P. Fish and fish side streams are valuable sources of high-value components. Food Qual. Saf. 2019, 3, 209-226. [CrossRef]

10. Pasupuleti, V.K.; Braun, S. State of the art manufacturing of protein hydrolysates. In Protein Hydrolysates in Biotechnology; Pasupuleti, V.K., Demain, A.L., Eds.; Springer: Dordrecht, The Netherlands; Heidelberg, Germany; London, UK; New York, NY, USA, 2010.

11. Halim, N.R.A.; Yusof, H.M.; Sarbon, N.M. Functional and bioactive properties of fish protein hydrolysates and peptides: A comprehensive review. Trends Food Sci. Technol. 2016, 51, 24-33. [CrossRef]

12. Villamil, O.; Vaquiro, H.; Solanilla, J.F. Fish viscera protein hydrolysates: Production, potential applications and functional and bioactive properties. Food Chem. 2017, 224, 160-171. [CrossRef] [PubMed]

13. Song, H.; Meng, M.; Cheng, X.; Li, B.; Wang, C. Effect of collagen hydrolysates from silver carp (Hypophthalmichthys molitrix) skin on UV-induced photoaging in mice: Molecular weight affects skin repair. Food Funct. 2017, 8, 1538-1546. [CrossRef] [PubMed]

14. Dong, S.; Zeng, M.; Wang, D.; Liu, Z.; Zhao, Y.; Yang, H. Antioxidant and biochemical properties of protein hydrolysates prepared from silver carp (Hypophthalmichthys molitrix). Food Chem. 2008, 107, 1485-1493. [CrossRef]

15. Jiang, H.; Tong, T.; Sun, J.; Xu, Y.; Zhao, Z.; Liao, D. Purification and characterization of antioxidative peptides from round scad (Decapterus maruadsi) muscle protein hydrolysate. Food Chem. 2014, 154, 158-163. [CrossRef]

16. Liu, R.; Xing, L.; Fu, Q.; Zhou, G.H.; Zhang, W.G. A review of antioxidant peptides derived from meat muscle and by-products. Antioxidants 2016, 5, 32. [CrossRef]

17. Grigore-Gurgu, L.; Crăciunescu, O.; Aprodu, I.; Bolea, C.A.; Iosăgeanu, A.; Petre, B.A.; Bahrim, G.E.; Oancea, A.; Stănciuc, N. Tailoring the health-promoting potential of protein hydrolysate derived from fish wastes and flavonoids from yellow onion skins: From binding mechanisms to microencapsulated functional ingredients. Biomolecules 2020, 10, 1416. [CrossRef]

18. Iosageanu, A.; Oancea, A.; Ilie, D.; Anton, E.D.; Craciunescu, O. The effect of fish bone bioactive peptides on the wound healing process: An in vitro study on keratinocytes. Rom. Biotechnol. Lett. 2021, 26, 2692-2699. [CrossRef]

19. Razali, A.N.; Sarbon, N.M.; Amin, A.M. Antioxidant activity and functional properties of fractionated cobia skin gelatin hydrolysate at different molecular weight. Int. Food Res. J. 2015, 22, 651e660.

20. Ngo, D.H.; Ryu, B.; Vo, T.S.; Himaya, S.W.A.; Wijesekara, I.; Kim, S.K. Free radical scavenging and angiotensin-I converting enzyme inhibitory peptides from Pacific cod (Gadus macrocephalus) skin gelatin. Int. J. Biol. Macromol. 2011, 49, 1110-1116. [CrossRef] 
21. Kumar, N.S.S.; Nazeer, R.A.; Jaiganesh, R. Purification and identification of antioxidant peptides from the skin protein hydrolysate of two marine fishes, horse mackerel (Magalaspis cordyla) and croaker (Otolithes ruber). AminoAcids 2012, 5, 1641-1649.

22. Guo, L.; Hou, H.; Li, B.; Zhang, Z.; Wang, S.; Zhao, X. Preparation, isolation and identification of iron-chelating peptides derived from Alaska pollock skin. Process Biochem. 2013, 48, 988-993. [CrossRef]

23. De Luca, C.; Mikhal'chik, E.V.; Suprun, M.V.; Papacharalambous, M.; Truhanov, A.I.; Korkina, L.G. Skin antiageing and systemic redox effects of supplementation with marine collagen peptides and plant-derived antioxidants: A single-blind case-control clinical study. Oxid. Med. Cell. Longev. 2016, 4389410. [CrossRef] [PubMed]

24. Ma, Q.; Liu, Q.; Yuan, L.; Zhuang, Y. Protective effects of LSGYGP from fish skin gelatin hydrolysates on UVB-induced MEFs by regulation of oxidative stress and matrix metalloproteinase activity. Nutrients 2018, 10, 420. [CrossRef] [PubMed]

25. Liang, J.; Pei, X.; Zhang, Z.; Wang, N.; Wang, J.; Li, Y. The protective effects of long-term oral administration of marine collagen hydrolysate from chum salmon on collagen matrix homeostasis in the chronological aged skin of Sprague-Dawley male rats. J. Food Sci. 2010, 75, H230-H238. [CrossRef] [PubMed]

26. Chen, Y.P.; Wu, H.T.; Wang, G.H.; Liang, C.H. Improvement of skin condition on skin moisture and anti-melanogenesis by collagen peptides from milkfish (Chanos chanos) scales. IOP Conf. Ser. Mater. Sci. Eng. 2018, 382, 022067. [CrossRef]

27. Chen, T.; Hou, H.; Fan, Y.; Wang, S.; Chen, Q.; Si, L.; Li, B. Protective effect of gelatin peptides from pacific cod skin against photoaging by inhibiting the expression of MMPs via MAPK signaling pathway. J. Photochem. Photobiol. B Biol. 2016a, 165, 34-41. [CrossRef]

28. Zhang, L.; Zheng, Y.; Cheng, X.; Meng, M.; Luo, Y.; Li, B. The anti-photoaging effect of antioxidant collagen peptides from silver carp (Hypophthalmichthys molitrix) skin is preferable to tea polyphenols and casein peptides. Food Funct. 2017, 8, 1698-1707. [CrossRef]

29. Hong, H.; Fan, H.; Chalamaiah, M.; Wu, J. Preparation of low molecular weight collagen hydrolysates (peptides): Current progress, challenges, and future perspectives. Food Chem. 2019, 301, 125222. [CrossRef] [PubMed]

30. Kim, S.Y.; Se, J.Y.; Kim, S.K. Purification and characterization of antioxidant peptide from hoki frame protein by gastrointestinal digestion. J. Nutr. Biochem. 2007, 18, 31-38. [CrossRef]

31. Je, J.Y.; Qian, Z.J.; Byun, H.G.; Kim, S.K. Purification and characterization of an antioxidant peptide obtained from tuna backbone protein by enzymatic hydrolysis. Process Biochem. 2007, 42, 840-846. [CrossRef]

32. Slizyte, R.; Mozuraitytè, R.; Martínez-Alvarez, O.; Falch, E.; Fouchereau-Peron, M.; Rustad, T. Functional, bioactive and antioxidative properties of hydrolysates obtained from cod (Gadus morhua) backbones. Process Biochem. 2009, 44, 668-677. [CrossRef]

33. Fernandes, M.M.; Rivera, D.; Francesko, A.; Slizyte, R.; Mozuraityte, R.; Rommi, K.; Lantto, R.; Tzanov, T. Bio/sonochemical conversion of fish backbones into bioactive nanospheres. Process Biochem. 2015, 50, 1843-1851. [CrossRef]

34. Ding, D.; Du, B.; Zhang, C.; Zaman, F.; Huang, Y. Isolation and identification of an antioxidant collagen peptide from skipjack tuna (Katsuwonus pelamis) bone. RSC Adv. 2019, 9, 27032-27041. [CrossRef]

35. Chen, X.; Fang, F.; Wang, S. Physicochemical properties and hepatoprotective effects of glycated Snapper fish scale peptides conjugated with xylose via maillard reaction. Food Chem. Toxicol. 2020, 137, 111115. [CrossRef] [PubMed]

36. Yi, J.; de Gobba, C.; Skibsted, L.H.; Otte, J. Angiotensin-I converting enzyme inhibitory and antioxidant activity of bioactive peptides produced by enzymatic hydrolysis of skin from grass carp (Ctenopharyngodon idella). Int. J. Food Prop. 2016, 20, 1129-1144. [CrossRef]

37. Nery, E.M.; Martinez, R.M.; Velasco, M.V.R.; Baby, A.R. A short review of alternative ingredients and technologies of inorganic UV filters. J. Cosmet. Dermatol. 2021, 20, 1061-1065. [CrossRef] [PubMed]

38. Morocho-Jacome, A.L.; Freire, T.B.; de Oliveira, A.C.; de Almeida, T.S.; Rosado, C.; Velasco, M.V.R.; Baby, A.R. In vivo SPF from multifunctional sunscreen systems developed with natural compounds - a review. J. Cosmet. Dermatol. 2021, 20, 729-737. [CrossRef] [PubMed]

39. Qin, D.; Lee, W.H.; Gao, Z.; Zhang, W.; Peng, M.; Sun, T.; Gao, Y. Protective effects of antioxidin-RL from Odorrana livida against ultraviolet B-irradiated skin photoaging. Peptides 2018, 101, 124-134. [CrossRef]

40. Zhang, H.; Pan, D.; Dong, Y.; Su, W.; Su, H.; Wei, X.; Yang, C.; Jing, L.; Tang, X.; Li, X.; et al. Transdermal permeation effect of collagen hydrolysates of deer sinew on mouse skin, ex vitro, and antioxidant activity, increased type I collagen secretion of percutaneous proteins in NIH/3T3 cells. J. Cosmet. Dermatol. 2019, 19, 519-528. [CrossRef]

41. Chai, H.J.; Li, J.H.; Huang, H.N.; Li, T.L.; Chan, Y.L.; Shiau, C.Y.; Wu, C.J. Effects of sizes and conformations of fish-scale collagen peptides on facial skin qualities and transdermal penetration efficiency. J. Biomed. Biotechnol. 2010, 757301. [CrossRef]

42. Lee, H.J.; Jang, H.L.; Ahn, D.K.; Kim, H.J.; Jeon, H.Y.; Seo, D.B.; Lee, J.H.; Choi, J.K.; Kang, S.S. Orally administered collagen peptide protects against UVB-induced skin aging through the absorption of dipeptide forms, Gly-Pro and Pro-Hyp. Biosci. Biotechnol. Biochem. 2019, 83, 1146-1156. [CrossRef] [PubMed]

43. Schieber, M.; Chandel, N.S. ROS function in redox signaling and oxidative stress. Curr. Biol. 2014, 24, R453-R462. [CrossRef] [PubMed]

44. Ayala, A.; Munoz, M.F.; Arguelles, S. Lipid peroxidation: Production, metabolism and signaling mechanisms of malondialdehyde and 4-hydroxy-2-nonenal. Oxid. Med. Cell. Longev. 2014, 360438. [CrossRef] [PubMed] 
45. Gao, R.; Yu, Q.; Shen, Y.; Chu, Q.; Chen, G.; Fen, S.; Yang, M.; Yuan, L.; McClements, D.J.; Sun, Q. Production, bioactive properties, and potential applications of fish protein hydrolysates: Developments and challenges. Trends Food Sci. Technol. 2021, 110, 687-699. [CrossRef]

46. Wang, W.Y.; Zhao, Y.Q.; Zhao, G.X.; Chi, C.F.; Wang, B. Antioxidant peptides from collagen hydrolysate of redlip croaker (Pseudosciaena polyactis) scales: Preparation, characterization, and cytoprotective effects on $\mathrm{H}_{2} \mathrm{O}_{2}$-damaged HepG2 cells. Mar. Drugs 2020, 18, 156. [CrossRef] [PubMed]

47. Chen, T.; Hou, H.; Lu, J.; Zhang, K.; Li, B. Protective effect of gelatin and gelatin hydrolysate from salmon skin on UV irradiationinduced photoaging of mice skin. J. Ocean Univ. China 2016, 15, 711-718. [CrossRef]

48. Hruza, L.L.; Pentland, A.P. Mechanisms of UV-induced inflammation. J. Invest. Dermatol. 1993, 100, S35-S41. [CrossRef]

49. Vieyra-Garcia, P.A.; Wolf, P. From early immunomodulatory triggers to immunosuppressive outcome: Therapeutic implications of the complex interplay between the wavebands of sunlight and the skin. Front. Med. 2018, 5, 232. [CrossRef]

50. Vaure, C.; Liu, Y. A comparative review of toll-like receptor 4 expression and functionality in different animal species. Front. Immunol. 2014, 5, 316. [CrossRef]

51. Ciesielska, A.; Matyjek, M.; Kwiatkowska, K. TLR4 and CD14 trafficking and its influence on LPS-induced pro-inflammatory signaling. Cell. Mol. Life Sci. 2021, 78, 1233-1261. [CrossRef]

52. Shim, D.W.; Heo, K.H.; Kim, Y.K.; Sim, E.J.; Kang, T.B.; Choi, J.W.; Sim, D.W.; Cheong, S.H.; Lee, S.H.; Bang, J.K.; et al. Antiinflammatory action of an antimicrobial model peptide that suppresses the TRIF-dependent signaling pathway via inhibition of toll-like receptor 4 endocytosis in lipopolysaccharide-stimulated macrophages. PLoS ONE 2015, 10, e0126871. [CrossRef]

53. Sarkar, R.; Arora, P.; Garg, K.V. Cosmeceuticals for hyperpigmentation: What is available? J. Cutan. Aesthet. Surg. 2013, 6, 4-11. [CrossRef]

54. Schurink, M.; van Berkel, W.J.H.; Wichers, H.J.; Boeriu, C.G. Novel peptides with tyrosinase inhibitory activity. Peptides 2007, 28, 485-495. [CrossRef]

55. Sugihara, F.; Inoue, N. Clinical effects of collagen hydrolysates ingestion on UV-induced pigmented spots of human skin: A preliminary study. Health Sci. 2012, 28, 153-156.

56. Del Bino, S.; Duval, C.; Bernerd, F. Clinical and biological characterization of skin pigmentation diversity and its consequences on UV impact. Int. J. Mol. Sci. 2018, 19, 2668. [CrossRef]

57. Koike, S.; Yamasaki, K. Melanogenesis connection with innate immunity and toll-like receptors. Int. J. Mol. Sci. 2020, 21, 9769. [CrossRef] [PubMed]

58. Yazawa, K.; Numata, K. Recent advances in chemoenzymatic peptide syntheses. Molecules 2014, 19, 13755-13774. [CrossRef]

59. Karami, Z.; Akbari-adergani, B. Bioactive food derived peptides: A review on correlation between structure of bioactive peptides and their functional properties. J. Food Sci. Technol. 2019, 56, 535-547. [CrossRef] [PubMed]

60. Barzideh, Z.; Latiff, A.A.; Gan, C.Y.; Abedin, M.Z.; Alias, A.K. ACE inhibitory and antioxidant activity of collagen hydrolysates from the ribbon jellyfish (Chrysaora sp.). Food Technol. Biotechnol. 2014, 52, 495-504. [CrossRef]

61. Wang, B.; Wang, Y.M.; Chi, C.F.; Luo, H.Y.; Deng, S.G.; Ma, J.Y. Isolation and characterization of collagen and antioxidant collagen peptides from scales of croceine croaker (Pseudosciaena crocea). Mar. Drugs 2013, 11, 4641-4661. [CrossRef]

62. Ngo, D.H.; Kim, S.J. Marine bioactive peptides as potential antioxidants. Curr. Protein Pept. Sci. 2013, 14, 189-198. [CrossRef]

63. Ajibola, C.F.; Fashakin, J.B.; Fagbemi, T.N.; Aluko, R.E. Effect of peptide size on antioxidant properties of African yam bean seed protein hydrolysate fractions. Int. J. Mol. Sci. 2011, 12, 6685-6702. [CrossRef]

64. Huang, C.Y.; Wu, C.H.; Li, Y.H.; Kuo, J.M. Evaluation of iron-binding activity of collagen peptides prepared from the scales of four cultivated fishes in Taiwan. J. Food Drug. Anal. 2015, 23, 671-678. [CrossRef]

65. Nwachukwu, I.D.; Aluko, R.E. Structural and functional properties of food protein-derived antioxidant peptides. J. Food Biochem. 2019, 43, e12761. [CrossRef]

66. Zou, T.B.; He, T.P.; Li, H.B.; Tang, H.W.; Xia, E.Q. The structure-activity relationship of the antioxidant peptides from natural proteins. Molecules 2016, 21, 72. [CrossRef] [PubMed]

67. Wu, R.; Wu, C.; Liu, D.; Yang, X.; Huang, J.; Zhang, J.; Liao, B.; He, H.; Li, H. Overview of antioxidant peptides derived from marine sources: The sources, characteristic, purification, and evaluation methods. Appl. Biochem. Biotechnol. 2015, 176, 1815-1833. [CrossRef]

68. Stefan, L.M.; Iosageanu, A.; Ilie, D.; Stanciuc, A.M.; Matei, C.; Berger, D.; Craciunescu, O. Extracellular matrix biomimetic polymeric membranes enriched with silver nanoparticles for wound healing. Biomed. Mater. 2021, 16, 035010. [CrossRef] [PubMed]

69. Le Goic, N.; Hegaret, H.; Boulais, M.; Beguel, J.P.; Lambert, C.; Fabioux, C.; Soudant, P. Flow cytometric assessment of morphology, viability, and production of reactive oxygen species of Crassostrea gigas oocytes. Application to toxic dinoflagellate (Alexandrium minutum) exposure. Cytometry A. 2014, 85A, 1049-1056. [CrossRef] [PubMed]

70. Mansour, R.B.; Gargouri, B.; Bouaziz, M.; Elloumi, N.; Jilani, I.B.; Ghrabi, Z.; Lassoued, S. Antioxidant activity of ethanolic extract of inflorescence of Ormenis Africana in vitro and in cell cultures. Lipids Health Dis. 2011, 10, 78-85. [CrossRef]

71. Craciunescu, O.; Moldovan, L.; Moisei, M.; Trif, M. Liposomal formulation of chondroitin sulfate enhances its antioxidant and anti-inflammatory potential in L929 fibroblast cell line. J. Liposome Res. 2013, 23, 145-153. [CrossRef] [PubMed]

72. Cho, B.R.; Jun, H.J.; Thach, T.T.; Wu, C.; Lee, S.J. Betaine reduces cellular melanin content via supression of microphthalmiaassociated transcription factor in B16-F1 murine melanocytes. Food Sci. Biotechnol. 2017, 26, 1391-1397. [CrossRef] [PubMed] 
73. Lee, D.H.; Kim, D.H.; Oh, I.Y.; Kim, S.Y.; Lim, Y.Y.; Kim, H.M.; Kim, Y.H.; Choi, Y.M.; Kim, S.E.; Kim, B.J.; et al. Inhibitory effects of Saururi chinensis extracts on melanin biosynthesis in B16F10 melanoma cells. Biol. Pharm. Bull. 2013, 36, 772-779. [CrossRef] [PubMed]

74. Gaspar-Pintiliescu, A.; Oancea, A.; Cotarlet, M.; Vasile, A.M.; Bahrim, G.E.; Shaposhnikov, S.; Craciunescu, O.; Oprita, E.I. Angiotensin-converting enzyme inhibition, antioxidant activity and cytotoxicity of bioactive peptides from fermented bovine colostrum. Int. J. Dairy Technol. 2020, 73, 108-116. [CrossRef]

75. Wu, R.; Chen, L.; Liu, D.; Huang, J.; Zhang, J.; Xiao, X.; Lei, M.; Chen, Y.; He, H. Preparation of antioxidant peptides from salmon byproducts with bacterial extracellular proteases. Mar. Drugs 2017, 15, 4. [CrossRef] 